\title{
Excess Dividend Smoothing
}

\author{
by \\ Yufeng $\mathrm{Wu}$ \\ Submitted in Partial Fulfillment of the \\ Requirements for the Degree \\ Doctor of Philosophy
}

Supervised by

Professor Toni M. Whited

Business Administration

Simon School of Business

University of Rochester

Rochester, New York

2015 


\section{Biographical Sketch}

Yufeng Wu was born in Wuhan, China on December 18, 1988. She received her Bachelor of Business Administration degree from the University of Hong Kong with First Class Honors . She enrolled in the doctoral program of the Simon Business School at the University of Rochester in 2010, with a concentration in Finance and minor in Macroeconomics. She was awarded a doctoral student fellowship from 2010 to 2014 and earned a Master of Science Degree in Business Administration from the University of Rochester in 2013. Yufeng's research interest spans the areas of corporate governance, capital structure and payout policy. She is also interested in labor search and optimal contracting. Her research in empirical corporate finance at the University of Rochester was conducted under the supervision of Professor Toni M. Whited. 


\section{Acknowledgments}

I am deeply indebted to my advisor Professor Toni Whited for her continuous support and encouragement. I thank my thesis committee members, Professor Ron Kaniel, Professor Olga Itenberg and Professor Jerry Warner for their invaluable guidance throughout. I would also like to thank Ruoyan Huang, Jay Kahn, Yunjeen Kim, Yang Liu, Boris Nikolov, Robert Parham, Robert Ready, Bill Schwert, Erin Smith, Mihail Velikov and all seminar participants at Baruch College, Johns Hopkins University, Indiana University, Washington University in St.Louis, University of South Carolina, University of Illinois, University of Rochester, University of Utah and University of Washington for helpful discussions and comments. 


\section{Abstract}

I find that dividends are a strong predictor of forced executive turnover, which suggests that managerial career concerns can be an important force behind observed dividend smoothness. I study the effect of this channel by developing a dynamic agency model in which dividends signal the firm's persistent earnings. In equilibrium, dividends and earnings are informational substitutes. Stock prices react to both earnings announcements and dividend changes, and this price reaction has a first-order effect on executive turnover. Managers, therefore, smooth dividends relative to earnings to withhold negative news and lower their turnover risk. Empirical estimates of the model parameters imply that $38 \%$ of observed dividend smoothness is turnover-induced. Having a turnover risk leads managers to smooth dividends excessively, compared to the level that maximizes the shareholders' wealth. This excess dividend smoothing destroys firm value by $2.84 \%$. 


\section{Contributors and Funding Sources}

The work in this dissertation has been conducted independently without outside funding support, under the supervision of Professors Olga Itenberg, Ron Kaniel, Jerry Warner, and Toni Whited of the Department of Finance in the Simon Business School at the University of Rochester. Graduate study was supported by a doctoral student fellowship from the Simon Business School. 


\section{Table of Contents}

Biographical Sketch ii

Acknowledgments

Abstract iv

Contributors and Funding Sources $\quad$ v

List of Tables viii

List of Figures $\quad$ ix

1 Introduction 1

2 Modeling $\quad 8$

2.1 Basic Setup . . . . . . . . . . . . . . . . 9

2.2 Managers' Utility Maximization . . . . . . . . . . . . . . . . . . 11

2.3 Shareholders' Information Set . . . . . . . . . . . . . . . . . . . . 12

2.4 The State-Contingent Turnover Risk . . . . . . . . . . . . . . . . 14

2.5 Equilibrium Characterization ................ 15

2.6 Dividend Smoothing and Manager Well-being . . . . . . . . . . 16 
$\begin{array}{llr}3 & \text { Data } & 20\end{array}$

3.1 Sample Construction . . . . . . . . . . . . . . . . 20

3.2 Executive Turnover . . . . . . . . . . . . . . . . . . . . . 21

3.3 Dividend Smoothness . . . . . . . . . . . . . . . . . . . . 22

4 Results $\quad 24$

4.1 Identification . . . . . . . . . . . . . . . . . . . . 24

4.2 Main Results . . . . . . . . . . . . . . . . 26

4.3 Counterfactuals . . . . . . . . . . . . . . . . . . . . 28

4.4 Subsample Estimations . . . . . . . . . . . . . . . . . . . . . 32

$\begin{array}{llr}5 & \text { Robustness } & 37\end{array}$

5.1 Lumpy Investments . . . . . . . . . . . . . . . . . . . . . 38

5.2 Stochastic Issuance Cost . . . . . . . . . . . . . . . . . . . . . 39

5.3 Earnings Management . . . . . . . . . . . . . . . . . . . . . 39

5.4 Executives' Outside Opportunities . . . . . . . . . . . . . . . . . . 40

5.5 Executives' Stock Options . . . . . . . . . . . . . . . . . 41

5.6 Executives' Risk Aversion . . . . . . . . . . . . . . . . . . 42

5.7 Board's Entrenchment . . . . . . . . . . . . . . . 43

5.8 Asymmetric Learning Speed . . . . . . . . . . . . . . . . . . . 44

6 Conclusion $\quad 45$

$\begin{array}{ll}\text { Appendix A Numerical Solution } & 47\end{array}$

$\begin{array}{lll}\text { Appendix B Estimation Procedure } & 51\end{array}$ 


\section{List of Tables}

1 Variable Description ................. 66

2 Summary Statistics . . . . . . . . . . . . . . . . 67

$3 \quad$ Simulated Moments Estimation: Full Sample . . . . . . . . . . . . . 68

$4 \quad$ Predicting Forced Turnover _. . . . . . . . . . . . . . . . . . . 69

$5 \quad$ Simulated Moments Estimation: No Agency Career Concern . . . . 70

$6 \quad$ Simulated Moments Estimation with Alternative Weight Matrix . . 71

7 Counterfactuals . . . . . . . . . . . . . . . . . 72

8 Subsample Estimation: Executive with High versus Low Reputation 73

9 Subsample Estimation: Executive with High versus Low Stock Compensation . . . . . . . . . . . . . . . . 74

10 Subsample Estimation: Early versus Late Sample Period . . . . . . 75

11 Robustness ........................ 76 


\section{List of Figures}

1 Timeline . . . . . . . . . . . . . . . . . . . 59

2 Policy Functions . . . . . . . . . . . . . . . . 60

3 The Information Content of Dividends . . . . . . . . . . . . . . . 61

4 Managers' Career Concern and Firm Policies . . . . . . . . . . . . . 62

$5 \quad$ Dividend Smoothing over Time . . . . . . . . . . . . . . 63

6 Industry Estimates . . . . . . . . . . . . . . . . . . . 64 


\section{Introduction}

Dividend smoothing is one of the oldest and most puzzling phenomena in corporate finance. On one hand, Miller and Modigliani (1961) show that in a frictionless market, managers cannot add value to a firm by changing the amount or timing of dividend payments. On the other hand, Lintner (1956) provides survey evidence showing that managers put high priority on the smoothness of dividends. In his seminal work, Linter argues that it is "[a] mix of attitudes and sentiments, pressures and sense of responsibility, standards of fairness and good management performance" that shapes the observed dividend stickiness among firms.

A natural question that rises from Linter's argument is what constitutes the "mix of attitudes and sentiment". It is mostly reflective of the shareholders' preferences? In addition to that, do managers also have their personal interests that induce them to smooth dividends? Though the existence of dividend smoothing is widely documented in the literature, little work has been done to disentangle the underlying driving forces behind this phenomenon.

This paper addresses this question by analyzing a new channel that leads 
managers to smooth dividends based on their career concerns in an informationasymmetric environment. I document that in the data, changes in dividend policy are indeed a strong negative predictor of executive turnover. Firms that have lowered their dividend payments experience on average one third higher forced executive turnover rates in the subsequent year. I also build and estimate a dynamic agency model that endogenize this negative dividend-turnover correlation and show that managers react to it. Having career concerns leads managers to smooth dividends excessively, compared to the level of smoothness that would have been chosen to maximize shareholders' value. This turnover-related channel accounts for $38 \%$ of the observed smoothness in the data, and it predicts a $2.84 \%$ firm value loss in equilibrium.

The model I consider features an information-asymmetric environment and a team of self-interested managers who face a turnover risk in each period. The managers choose the optimal firm policies to maximize the expected value of their lifetime utility, which is a weighted average of their expected future wage income and the value of their equity stake in the firm. Holding an equity stake aligns managers' incentives with the shareholders', but having career concerns diverges their personal-interests. Hence, the managers' optimal choice of firm investment, financing, and payout policies will be different from those that maximize the expected cash flows to the shareholders.

The model suggests two channels for dividend smoothing: First, dividend payments conveys information on the persistent earnings of a firm. This information content of dividends implies that the firm's stock prices always react to dividend changes. Due to signaling costs, the magnitude of the price reaction to dividend cuts is larger than that to dividend increases. Hence, having a stable dividend 
policy helps to protect the equity value of the firm. This first channel is frequently mentioned in the dividend smoothing literature, so inclusion of this mechanism in the model allows me to isolate the career concern channel.

The career concern channel states that the information conveyed by both earnings and dividends will influence decisions on managerial tenure. Therefore, managers treat dividends and earnings as informational substitutes based on their tenure decision, and this substitutability gives them a separate incentive to smooth dividends. In particular, they will be hesitant to increase dividends as earnings improve, because in such states, they are already far away from the turnover threshold. Thus, further increasing dividends brings them very little benefit. They will also be extremely reluctant to cut dividends when earnings decline in order to withhold the negative news and keep their turnover risk low. Hence, the executives' career concern amplifies the effect of dividend smoothing, and this amplification channel is the focus of my paper.

Quantifying the effects of the dividend smoothing channel is difficult in part because firms' turnover decisions and dividend payments are both endogenous. There is no obvious instrumental variable for the managers' career concerns ex-ante at the time when they set the optimal policies. In addition, although reduced-form regressions can deliver directional effects of proxies for career concerns on dividend smoothness, they cannot by nature address the extent to which smoothness is accounted by each potential dividend smoothing channel.

In this paper, I tackle these empirical challenges by estimating the model via simulated method of moments (SMM) on a set of frequent dividend payers using data from the 1992-2011 period. The estimation results confirm that both value- 
and turnover-induced dividend smoothing are present in the data and have large economic significance. In both the actual and simulated data, the average dismissal rate for top executives increases by roughly one-third following dividend cuts, after controlling for other firm- and executive-level characteristics. Managers choose smoother dividends in order to lower their turnover risk, and this incentive explains approximately $38 \%$ of the observed dividend smoothness in the data. Because turnover is only a transfer of wage income from the incumbent to future managers, this type of dividend smoothing is considered excessive from the shareholders' point of view. Dividends would be markedly more responsive to earnings if set directly by shareholders to maximize the firm value.

My estimation provides three further results. First, accounting for the relation between dividend policy and executive turnover is crucial for the model to match actual moments on firm payouts. Otherwise, a standard dynamic investment model with constant turnover always fails to generate the small variance of dividends or to reproduce the low responsiveness of dividends to earnings changes. Second, a model incorporating both types of dividend smoothing is able to match not only the average low responsiveness of dividends but also the wide cross-industry dispersion in dividend smoothness. The effect of turnover-induced dividend smoothing is more pronounced within riskier and more opaque industries. Third, I perform subsample estimations to explore the interaction between managers' turnover risk, their compensation structure, and the choice of dividend smoothness. I find that managers smooth dividends more aggressively when they are less reputable and facing higher risk of being fired. They also smooth dividends more when they hold less equity shares in the firm, so that there is a greater degree of incentive misalignment. These findings are consistent with my model predictions and further support the validity of the excess dividend smoothing story. 
The observation that firms tend to smooth dividend payments goes back as far as 60 years, with the evidence in Lintner (1956) that managers are primarily concerned with the stability of dividends. They behave as if there were a premium associated with a stable dividend policy. This observation is further confirmed by Fama and Babiak (1968), DeAngelo and DeAngelo (1990), and Brav et al. (2005). In particular, Brav et al. (2005) document that firms may take costly actions to avoid decreasing dividends, such as issuing new equity or even cutting positive net present value projects. This finding contradicts the predictions in a typical Modigliani and Miller world, where dividend changes are among many value-neutral policies that a firm can implement.

These observations have inspired many subsequent studies. These studies use different data and experimental settings to understand why stable dividends are value enhancing from a firm's perspective and analyze the underlying market frictions that drive this smoothness. For example, Easterbrook (1984) argues that consistent dividend payments keep a firm in the capital market and motivate efficient public monitoring, which, in turn, raises firm value. In the same spirit, Allen, Bernardo, and Welch (2000) emphasize that ex-post stable high dividends attract more institutional investors, who can process information more efficiently and better discipline the management team. Using a different data set, Dewenter and Warther (1998) study the payout policies of keiretsu in Japan. Their research also supports the idea that firms smooth dividends to alleviate the cost associated with information asymmetry and to reduce free cash flow problems in corporations. One potential issue with these prior studies is their implicit assumption that dividends only reflect shareholders' desire to maximize the stock price. However, in reality, we know that managers, especially top financial executives, exert 
a significant influence on a firm's payout decisions. They have an extra incentive to smooth dividends if their personal well-being is tied to the firm's dividend stability. Whether this incentive exists and how much smoothness in the data it can explain is the main focus of this paper.

Kaplan and Reishus (1990) are among the first to study the implications of dividend policy on managers' wealth. They document that top executives in firms that announce dividend cuts are $50 \%$ less likely to be appointed outside directors, and they have a higher probability of losing their outside directorship three years following the dividend cuts. In a more recent study, Parrino, Sias, and Starks (2003) find that firms with dividend cuts or eliminations experience a greater institutional exodus, which reduces the likelihood that a top executive be promoted to CEO internally. These results are all consistent with the idea that dividend instability hurts the top executives' well-being. However, the prior literature does not examine whether managers react to such incentives by choosing an inter-temporally smoother dividend policy, which is the main research question of this paper.

My paper is most closely related to Lambrecht and Myers $(2012,2014)$, who are the first to analyze firms' payout decisions using a dynamic agency model. Under certain simplifying assumptions, they derive a closed-form solution for firm-level total payout, which follows Lintner's target adjustment equation. While their paper focuses on the role of cash redistribution as a contracting tool, this paper examines the information content of dividends on firm earnings and executive turnover. I test the empirical relevance of the turnover-induced dividend smoothing story and present the quantitative as well as the qualitative effects. Mahmudi and Pavlin (2013) also estimate a dynamic model to examine how a firm's payout policy is determined in conjunction with its investment and financing decisions. 
Their paper, however, does not directly tackle the question of why firms smooth payouts, whereas, in this paper, I test and confirm that executives' career concerns are an economically important factor that drives dividend smoothing.

Another related paper is Fudenburg and Tirole (1995), who build a theory of earnings smoothing based on managers' career concern. In their model, all reported earnings are paid to the owner as dividends, and hence their model naturally generates the smoothing of dividends. However, their work is different from mine in four important aspects. First, their baseline model does not allow time-varying investment and retained earnings, which generates a mechanical link between earnings and dividend smoothing. Second, in their extension when cash retention is considered, the equilibrium dividend policy is either non-informative or fully-revealing. Therefore, it does not capture the idea that dividends and earnings reports signal different aspects of a firm's profitability and hence are informational substitutes. Third, they analyze firms' smoothing of earnings and dividends against some unobservable profitability measures instead of focusing on how dividends vary relative to the reported earnings. Lastly, their model is qualitative in nature. They do not attempt to take it to data and quantify the impact of career concern on managers' smoothing behaviors.

The remainder of this paper is organized as follows: Chapter 2 discusses the model and its underlying economic intuitions; Chapter 3 describes the data; Chapter 4 outlines the estimation strategies and reports the results; Chapter 5 presents robustness checks; Chapter 6 concludes and indicates some future directions. 


\section{Modeling}

Models on firm payouts, for example, Allen, Bernardo, and Welch (2000) and Miller and Rock (1985), are usually based on the implicit assumption that dividend policy only reflects shareholders' desire to maximize the stock price. However, the recent literature puts increasing emphasis on how managers' self-interest can also shape a firm's financial decisions (Morellec, Nikolov, and Schürhoff, 2012; Nikolov and Whited, 2014). Following this strand of the literature, I build a dynamic model of self-interested managers who set the investment, financing, and payout policies each period to maximize the expected value of their utility. The model is in discrete time and infinite horizon. Managers are assumed to be risk-neutral. This risk-neutrality assumption captures the idea that the top executives who can influence a firm's policies are usually wealthy individuals, and they have good access to various investment and savings technologies. ${ }^{1}$ Shareholders observe the realized profit and reported policies, and they determine the firm's value on the stock market. The board of directors is in charge of the firm's executive turnover decisions. The remainder of this chapter provides more details on the model setup

\footnotetext{
${ }^{1}$ The model can also be extended to include risk-averse and habit-persistent agents as in Lambrecht and Myers (2012, 2014). Mathematically, making such an extension is equivalent to introducing a concave transformation on the managers' utility function, which gives them stronger incentives for smoothing.
} 
and qualitatively illustrates how managers' utility maximization determines firmlevel dividend smoothness. In the following chapters, I take the model to data and present the quantitative results.

\subsection{Basic Setup}

[Insert Figure 1]

Figure 1 illustrates the timeline of the model. In the model, firms have decreasing return-to-scale technology, and they use capital as the only input to generate per period after-tax profit:

$$
y\left(k_{t}, z_{t}, s_{t}\right)=\left(1-\tau_{c}\right) \times e^{z_{t}} e^{s_{t}} k_{t}^{\theta},
$$

in which $\theta$ is the curvature of a firm's production function, and $\tau_{c}$ is the corporate tax rate. $z_{t}$ represents a shock specific to each firm-management match, which follows an $\mathrm{AR}(1)$ process:

$$
z_{t}=\rho_{z} \times z_{t-1}+\epsilon_{z, t}, \quad \epsilon_{z, t} \stackrel{i i d}{\sim} N\left(0, \sigma_{z}^{2}\right)
$$

It is worth notice that as in Cao and Wang (2013); Holmström (1999); Mortensen and Pissarides (1994), $z_{t}$ should be understood as the match quality between the executives and the firm. It is time varying and does not translate directly into some fixed properties of the firm or the person. As Cao and Wang (2013) argue, a high match qualify means that the executive's talent and experience fits 
well with the firm size, its nature of business, strategic direction and organizational culture in this particular time frame. An executive well-matched with the firm at one point of time may not be well-matched with the same firm at another point of time, due to the change in the above executive or firm-level characteristics.

$s_{t}$ is a transitory earnings shock, $s_{t} \stackrel{i i d}{\sim} N\left(0, \sigma_{s}^{2}\right)$, which also enters exponentially into the firm's current earnings, but it does not have any implication on the future cash flows. At the beginning of each period, the two shocks, $z_{t}$ and $s_{t}$, are realized. Managers observe them separately, and they base the firm's investment, financing, and payout decisions on the realized values. A firm's investment, $i_{t}$, is defined as:

$$
i_{t}=k_{t}-k_{t-1} \times(1-\delta),
$$

where $\delta$ stands for the depreciation rate of physical assets. A firm can either finance investment using its holdings of liquid assets, $l_{t}$, or it can go to the capital market and issue new equity. On the other hand, if a firm wants to dispose of idle cash, it can either pay dividends or make repurchases. Dividends are subject to a personal tax rate, $\tau_{p}$, at the time of distribution. Equity issuance and repurchases are associated with a quadratic financing $\operatorname{cost} \Lambda($.$) :$

$$
\Lambda\left(e_{t}\right)=v_{1} \times k_{t}+v_{2} \times \frac{e_{t}^{2}}{k_{t}}
$$

$e_{t}$ captures the net equity issuance, which is defined as the difference between equity issuance and share repurchases. Positive $e_{t}$ means that the firm is receiving cash inflow from its investors while negative $e_{t}$ means cash redistribution back to the shareholders. Empirically, firms pay sizeable fees for investment banking 
service when they make seasoned equity offerings (Gao and Ritter, 2010) or accelerated share repurchase (Dickinson, Kimmel, and Warfield, 2012). Asquith and Mullins (1986) and Corwin (2003) find that SEOs occur at discounts to market prices and that the discount increases with the size of the equity offering. Similarly, a large literature following Vermaelen (1981) documents that firms announce repurchases at a premium to the current share price. Equation (4) summarizes the effect of fees along with adverse selection in reduced-form. Assuming a convex cost structure implies that the cost of net issuance is lumpy, it increases monotonically with the size of issuance and exhibits increasing return to scale, consistent with the evidence presented in Warusawitharana and Whited (2012).

\subsection{Managers' Utility Maximization}

In the model, managers are offered compensation contracts consisting of two components: The first one is a fixed wage income per period, contingent on the managers staying with the firm. The second captures the managers' equity stake in the firm. In this paper, I am not trying to discuss the optimality of such a contract. Instead, I take the form of executive compensation that we see in the data and try to infer managers' policy choices based on the structure of their compensation package. In each period, managers choose the firm's investment, financing, and payout policies, $\Omega_{t}=\left\{i_{t}, e_{t}, l_{t}, d_{t}\right\}$, to maximize the discounted present value of their utility:

$$
U_{t}\left(z_{t}, s_{t}, d_{t-1}, k_{t-1}, l_{t-1}\right)=\max _{\Omega_{t}} \mathbb{E}\left[\sum_{s \geq t}\left(\prod_{s \geq v \geq t} \beta\left(1-\Phi_{v}\right)\right) w_{t}+\kappa^{i} V_{t}^{i}+\kappa^{m} V_{t}^{m}\right],
$$

subject to the sources and uses of funds constraint: 


$$
y_{t}-i_{t}+\tau_{c} \delta k_{t}+\left(l_{t-1}+k_{t-1}\right) \times\left[1+r_{f}\left(1-\tau_{c}\right)\right]+e_{t}-d_{t-1}-w_{t}-l_{t} \geq 0 .
$$

$U_{t}$ in Equation (5) stand for the managers' utility. $V_{t}^{i}$ and $V_{t}^{m}$ represent the intrinsic and the market value of the firm, respectively. The two measures are usually different because the investors do not directly observe the firm fundamentals. Managers care about the intrinsic value of the firm because they hold stocks and stock options of their own firm, the value of which is tied to the firm's intrinsic value over a long horizon. The market value of the firm is also relevant because managers can inherit the preferences from shareholders who need to trade for liquidity reasons (John and Williams, 1985). $\kappa^{m}+\kappa^{i}$ captures the managers' total equity stake in the firm. $w_{t}$ is the managers' wage income, which is modeled as a constant fraction, $\eta$, of the firm's steady state value. $\beta$ stands for managers' discount rate and $\Phi_{t}$ is a dummy variable indicating forced turnover. Once a manager leaves office, he keeps his equity stake, but forfeits his current, plus the expected value of all future wage income. Hence, from the managers' perspective, having a turnover risk is equivalent to increasing the discount factor on future wages from $(1-\beta)$ to $\left[1-\beta\left(1-\Phi_{t}\right)\right]$.

\subsection{Shareholders' Information Set}

One important friction embedded in the model is the information asymmetry between managers and shareholders. Unlike the managers who directly observe the underlying productivity shocks, the shareholders only see the realized profit, which is jointly determined by the persistent and transitory components. This profit is not a sufficient statistic for predicting the firm's future performance as uncertainty 
exists regarding the value of the individual shock process. Any piece of outside information that helps to disentangle $s_{t}$ from $z_{t}$ can improve the shareholders' knowledge of the firm's economic standing and allow them to set more efficient stock prices.

In the model, I let the shareholders extract information from all announced firm policies. To maintain tractability, I focus on the set of time-invariant linear forecasting rules, $\Gamma=\left\{\gamma_{0}, \gamma_{\hat{z}}, \gamma_{y}, \gamma_{\varphi}, \gamma_{\Omega}\right\}$, based on which the shareholders predict the value of $z_{t}$ as accurately as possible:

$$
\hat{z}_{t}=\gamma_{0}+\gamma_{\hat{z}} \times \hat{z}_{t-1}+\gamma_{y} \times y_{t}+\gamma_{\varphi} \times \varphi_{t}+\gamma_{\Omega} \times \Omega_{t} . \quad \Gamma=\arg \min \mathbb{E}\left|\hat{z}_{t}-z_{t}\right|,
$$

in which $\hat{z}_{t}$ denotes the shareholders' forecasted value of the persistent productivity shock. $y_{t}$ and $\Omega_{t}$ are the firm's profit and optimal policies, respectively. ${ }^{2} \varphi_{t}$ is an additional noisy signal observed by the shareholders: $\varphi_{t} \sim z_{t}+N\left(0, \sigma_{z}^{2}\right)$. Given the shareholders' forecast, $\hat{z}_{t}$, the firm's market value, $V_{t}\left(z_{t}, s_{t}, d_{t-1}, k_{t-1}, l_{t-1}\right)$, can be written recursively:

$V_{t}^{m}\left(z_{t}, s_{t}, d_{t-1}, l_{t-1}, k_{t-1}\right)=\max _{\Omega_{t}} U\left(1-\tau_{p}\right) d_{t}-e_{t}-\Lambda\left(e_{t}\right)+\beta\left(\mathbb{E}_{z_{t}=\hat{z}_{t}} V_{t+1}^{m}-\lambda \triangle d\right)$,

where $\Omega_{t}$ represents the optimal policies that maximize the managers' utility defined in Equation (5). This choice is not, in general, the same choice of $\Omega_{t}$ that would be made if the managers were maximizing the expected present value of cash flows to shareholders. For any given current state, $\left(z_{t}, s_{t}, d_{t-1}, k_{t-1}, l_{t-1}\right)$, the

\footnotetext{
${ }^{2}$ I use the scaled profit and firm policies by total asset size in the shareholders' forecasting equation.
} 
firm's equity value is less than it would be in the absence of misaligned incentives.

$\triangle d$ in Equation (8) represents the firm's dividend change from the last period, and it is truncated above at zero. From a firm's perspective, cutting dividends can destroy firm value by reducing institutional clients (Allen, Bernardo, and Welch, 2000), weakening public monitoring (Easterbrook, 1984) and aggravating the free cash flow problem (Leary and Michaely, 2011), and such costs are captured by the coefficient, $\lambda$. Note that, I am not trying to detail the mechanism behind this cost. Instead, I capture this effect in reduced form and estimate its magnitude, so that the model-generated dividend announcement returns match what is observed in the data. Empirically, it is widely documented that dividend changes are associated with abnormal stock returns, and this abnormal price effect is very robust regardless of whether the firm is simultaneously increasing other forms of payout (Michaely, Thaler, and Womack, 1995), whether the dividend change is induced by investment needs (Ghosh and Woolridge, 1989), or whether the firm makes contemporaneous earnings announcements (Aharony and Swary, 1980). This empirical evidence is consistent with the intuition that dividends play an important role in the information revelation, and the market is actively screening firms based on the observed dividend signals.

\subsection{The State-Contingent Turnover Risk}

For most dynamic investment models, the managers' turnover rate, $E\left(\Phi_{t}\right)$, is treated as an exogenous parameter and is assumed to be constant across time and states. In this paper, I deviate from this assumption by incorporating statecontingent turnover risk. More specifically, I assume that the board pulls the trigger when the firm's market price falls below a certain threshold given its asset 
values. A low market price indicates that the shareholders hold a pessimistic view towards the firm's future prospects. The board of directors is supposed to act in representation of the shareholders. Therefore, they will replace the incumbent management team following the price pressure:

$$
\Phi_{t}= \begin{cases}1, & V\left(z_{t}, s_{t}, d_{t-1}, k_{t-1}, l_{t-1} \mid \hat{z}_{t}\right) \leq \underline{V}\left(k_{t-1}, l_{t-1}\right) \\ 0, & \text { otherwise }\end{cases}
$$

If a firm decides to overturn its managers under the criteria described in Equation (9), it takes a random draw from the unconditional distribution of the matchspecific shock, $z_{\text {new }} \sim N\left(0, \frac{\sigma_{z}^{2}}{1-\rho_{z}^{2}}\right)$ and resets $z_{t}$ to $z_{\text {new }}-c$. This expression implies that having executive turnovers not only allows the firm to find more suitable managers, but also disrupts the firm's normal operations and entails an opportunity cost $c$. The magnitude of this cost determines the state-contingent turnover threshold. For each pair of $\left\{c ; k_{t-1}, l_{t-1}\right\}$, the board of directors has a unique choice of $\underline{V}$, which maximizes the firm's market value. ${ }^{3}$

\subsection{Equilibrium Characterization}

Table 1 summarizes the parameters in the model and lists the values used to calculate the baseline solution.

\section{[Insert Table 1]}

The model presented above can be condensed into a two-sided decision-making problem. An equilibrium is characterized by the following two incentive compatibility conditions: First, given the shareholders' forecasting decision, $\Gamma=$

\footnotetext{
${ }^{3}$ This result can be easily derived following the strict monotonicity of a firm's value function.
} 
$\left\{\gamma_{0}, \gamma_{\hat{z}}, \gamma_{y}, \gamma_{\varphi}, \gamma_{\Omega}\right\}$, managers set firm investment, financing, and payout policies in each period to maximize their expected utility. The second condition states that knowing the managers' decision-making process, $\Omega_{t}=\left\{i_{t}, e_{t}, l_{t}, d_{t}\right\}$, shareholders choose the optimal forecasting rule so that they make the best possible predictions of the underlying productivity process. When both conditions are satisfied, no party has an incentive to deviate from their current strategies. Hence, an equilibrium is achieved.

\section{[Insert Figure 2]}

Figure 2 depicts the managers' equilibrium choices of investment, equity issuance, share repurchases, and dividend payments in response to the persistent $\left(z_{t}\right)$ versus transitory productivity shock $\left(s_{t}\right)$. Figure 2 shows that a firm's investment, issuance, and repurchases ${ }^{4}$ react roughly symmetrically to $z_{t}$ and $s_{t}$, whereas for dividends, they react almost exclusively to the persistent productivity shock while any transitory cash flow has no notable effects. This is because the though dividends can boost the market prices for firms today, it will be very costly for firms with low future profitability to sustain the high levels of payments tomorrow. This unique characteristic allows shareholders to extract valuable information from the announced dividend policy.

\subsection{Dividend Smoothing and Manager Well-being}

This section examines the consequences of dividend changes on the managers' personal well-being. The results illustrate why it is utility-enhancing for the managers

\footnotetext{
${ }^{4} \mathrm{~A}$ firm's repurchases react almost symmetrically to the two shocks when the realized values of the shocks are low or moderately high. The firm's reaction can also be asymmetric when it has high asset values and faces very positive shocks. Such cases with asymmetric reactions, however, occur very rarely in my simulation.
} 
to choose a smooth dividend policy.

To see how managers are hurt by the announcement of dividend reductions, I simulate 100,000 hypothetical firms. I sort out the firms that cut dividends in year 1, and I track their economic conditions for the subsequent ten periods. I also create a matched sample by choosing a set of non-dividend cutting firms who have on average the same year-1 reported earnings as the dividend cutting sample and use them as controls.

\section{[Insert Figure 3]}

Figure 3 shows that dividend decreases are usually associated with well below average contemporary earnings. When firms cut dividends, it does not directly signal future decreases in earnings. Instead, it implies that large earnings shocks have already been realized and will have persistent effects on the firms' future performance. Consequently, such firms experience slower productivity reversals, and it takes longer for their earnings to converge back to the steady-state. These model predictions are consistent with the empirical evidence documented in Grullon, Michaely, Shlomo, and Thaler $(2005)^{5}$.

Moreover, dividend changes also influence the managers' turnover risk. Firms that decrease dividends experience on average one-third higher rates of forced turnover, compared to firms in the matching sample who report similar earnings but manage to increase or maintain their dividend levels. I repeat the above exercise for the sample of dividend-increasing firms and find similar qualitative effects.

\footnotetext{
${ }^{5}$ Grullon et al. (2005) find that including dividend change does not add to a model's predictive power on future earnings changes. However, current earnings increases/ declines accompanied by dividend movements in the same direction are less likely to be reversed in the future.
} 
However, quantitatively, the magnitudes of the effects are much weaker. This is because when a firm performs well, the turnover risk stays at a very low level, and its slope with respect to dividend changes is relatively flat. On the other hand, when the firm's performance deteriorates, the turnover risk increases and it becomes increasingly sensitive to the release of additional negative information. Hence, announcing a dividend cut will have a larger marginal effect on the expected turnover.

In anticipation of this effect, managers will be reluctant to raise dividends when earnings improve as well as to cut dividends when earnings decline, leading to a low responsiveness of dividends to earnings. Figure 4 illustrates this result graphically, in which I consider two model specifications: the baseline model and an alternative case where I assume that the shareholders extract information from the dividends, but the managers ignore this effect. Instead, they believe that their turnover risk is constant across time and states. This assumption brings us back to the first-best solution, in which the managers behave as if their personal interests were fully aligned with the shareholders when deciding the optimal policies.

\section{[Insert Figure 4]}

Figure 4 shows that when the managers anticipate the state-contingent turnover risk, they become more conservative in setting the rate of payments, which lowers the level of dividends. At the same time, dividends are markedly less responsive to earnings changes, reflected by a flatter slope of the dividend policy. This difference in slopes captures the amount of dividend smoothing induced by managers' career concerns, which is excessive compared to the level of smoothness that maximizes the shareholders' wealth. 
Having state-contingent turnover risk also influences firm value. On one hand, it allows the firm to retain a more efficient management team. On the other hand, anticipating this effect will distort the managers' incentives and make their policy choices deviate from the first-best case. More specifically, managers will hoard cash instead of paying out dividends in cash-rich states, which is costly because interest is taxed. They will also avoid cutting dividends to withhold bad information in a low cash-flow state, which may require issuing new equity or cutting investments. Figure 4 shows that managers choose lower and stickier dividends, make more repurchases, and issue slightly more equity when they expect their policies to influence the turnover risk. Such policy differences make the equilibrium firm value lower than in the first-best case. 


\section{Data}

This section offers a brief discussion of the datasets used to quantify the model. The data come from four sources: firm fundamentals come from Compustat; executive compensation data are from ExecuComp; dividend announcement dates and returns are from the CRSP daily file; and the top executive turnovers are from a hand-collected dataset based on Businessweek, Equilar, and The Wall Street Journal.

\subsection{Sample Construction}

To construct the sample, I start with all non-financial and non-utility firms on the merged CRSP and Compustat database from 1992 to 2011. Analyzing firms' dividend smoothing behavior requires that they provide sufficient dividend payment records, so that a reliable measure on the smoothness can be calculated. To meet this criterion, I restrict the sample to the set of frequent dividend-paying firms following three steps: In the first step, I remove all observations before a firm announces its first dividend and after it makes its last dividend payment. In the second step, I divide the sample into 11 overlapping 10-year sub-periods. For any given 10-year subsample, I only retain the firms that have made at least six 
positive dividend payments. According to this criterion, any firm with consecutive zero payments is to be dropped. Those firms are likely to differ systematically from the firms with consistent positive dividends and, therefore, I do not consider zero payments as a special form of smoothed dividends. In the third step, I compare the annualized split-adjusted dividend per share from Compustat and CRSP. I drop those observations where the reported data from the two sources are significantly different (the difference being larger than 10\%).

Next, I calculate the magnitude of the dividend price effect by focusing on the observations where the changes in split-adjusted dividend per share are larger than 10\%. I obtain the dates for the dividend change announcements from the CRSP daily event file, and I check whether these firms make any earnings disclosure in a 10-day window prior to the dividend announcements. I exclude the observations where the two types of events overlap. I calculate the three-day CAR around the dividend changes and use it to quantify the price effect. The CAR is insignificant for dividend increases, and it averages $-3 \%$ for dividend cuts. In terms of magnitude, this result lies in proximity to earlier studies (Aharony and Swary, 1980; Nissim and Ziv, 2001).

\subsection{Executive Turnover}

ExecuComp tracks top executives' compensation starting from 1992 onwards, where I retrieve data on the five highest paid managers' total annual compensation, their percentage of stock holdings, and the percentage of non-vested versus vested stock options. However, ExecuComp is not a good source of the turnover data for two reasons: 1) It does not always report the date when an executive leaves office and 2) the reason for departure indicated by the dataset is often vague and inac- 
curate. To overcome these issues, I hand-collect data from Businessweek, Equilar, and The Wall Street Journal. I define the year of "turnover" as the one in which the firm announces the departure of a top executive. Following Warner, Watts, and Wruck (1988) and Parrino, Sias, and Starks (2003), I classify a turnover as "forced" if a manager leaves a firm and does not find any new executive position within the next year, or if a manager is reported to have retired before the age of 60. I also do a Google search to supplement the data. If any reliable source points out that the turnover is performance-based, then I interpret it as "forced." If, on the other hand, the turnover is indicated to be driven by health issues, I classify it as "voluntary". The final sample consists of 10,827 distinct firm-executive pairs and 11,626 firm-year observations. The summary statistics are reported in Table 2.

[Insert Table 2]

\subsection{Dividend Smoothness}

Following Leary and Michaely (2011), I measure a firm's dividend smoothness using the speed of adjustment (SOA), which equals the estimated coefficient $\beta$ in the following regression:

$$
D_{i, t}-D_{i, t-1}=\alpha+\beta \times\left(T P R_{i} \times E_{i, t}-D_{i, t-1}\right)+\epsilon_{i, t}
$$

in which $D_{i, t}$ and $E_{i, t}$ refer to firm $i$ 's dividend and earnings per share at time $t$ after adjusting for stock splits. $T P R_{i}$ is the firm's target dividend payout ratio, which is defined as the median dividend-to-earnings ratio for firm $i$ over the 10-year 
window. In a hypothetical case where a firm always lets its dividends fluctuate proportionately with earnings, $\beta$ will have an estimated value of 1 . On the other extreme, if a firm keeps its dividend per share constant regardless of its earnings changes, then $\beta$ will take the value of 0 . In reality, a firm's dividend adjustment usually lies in between these two extremes, with a lower SOA implying that the dividends are smoother and less responsive to earnings changes. Figure 5 plots the time-series changes for dividend smoothing over the past 25 years.

\section{[Insert Figure 5]}

Figure 5 shows that the SOA of dividends has always been around 0.2, indicating that shocks to firms' earnings do not translate into proportional changes in dividends. Over time, the SOA of dividends has decreased slightly ${ }^{1}$ while the level of dividend per share has increased by roughly 50\%. Taking all this evidence together suggests that these frequent dividend payers have been increasing their distributions over time, and they distribute in an increasingly "smoother" fashion.

\footnotetext{
${ }^{1}$ This finding has also been documented by Skinner (2008) and Leary and Michaely (2011).
} 


\section{Results}

This section takes the model to data and presents the quantitative results. I first talk about the model identification and report the full sample parameter estimates. Based on this result, I perform two counterfactual exercises to quantify the amount of excess dividend smoothing. Finally, I present subsamples estimations to explore the relation between industry characteristics, executives' turnover risk, and dividend smoothness.

\subsection{Identification}

I estimate most parameters using simulated method of moments (SMM), the objective of which is to pick the set of parameters that make the simulated data track the actual data as closely as possible. For the rest of the parameters, I calculate their values separately outside of the model. For example, I set the risk-free rate, $r_{f}$, equal to the average real three-month Treasury bill rate. I set the dividend income tax, $\tau_{p}$, equal to the average tax disadvantage of personal income relative to capital gains, which is approximately $15 \%$ for my sample period. I set the corporate tax rate, $\tau_{c}$, to $35 \%$. In addition, I set the executives' stock holdings, $\kappa^{i}$, and wage compensation, $\eta$, to $1.13 \%$ and $0.10 \%$ of the steady-state firm value, 
respectively. These parameter choices match the average levels of executive compensation reported in ExecuComp.

I estimate the remaining 9 parameters $\left\{\rho_{z}, \sigma_{z}, \sigma_{s}, \theta, \nu_{1}, \nu_{2}, \delta, \kappa^{m}, c\right\}^{1}$ within the model by matching 17 moments. The success of this strategy depends critically on choosing the moments that are sensitive to variations of underlying structural parameters. On the other hand, I avoid "cherry-picking" by focusing on the moments that reflect important characteristics of the data.

The first two moments correspond to the two coefficients, $\left\{\beta_{k}, \beta_{y}\right\}$, in the following regression:

$$
\ln \left(y_{i, t}\right)=\beta_{y} \times \ln \left(y_{i, t-1}\right)+\beta_{k} \times \ln \left(k_{i, t}\right)-\beta_{y} \times \beta_{k} \times \ln \left(k_{i, t-1}\right)+\epsilon_{i, t},
$$

where $y_{i, t}$ is a firm's operating income and $k_{i, t}$ denotes the stock of physical capital. As argued by Cooper and Haltiwanger (2006), Equation (11) can be derived as an auxiliary equation from the firm's production function (Equation 1) and the profitability shock process. Hence, these moments are sensitive to the underlying parameter changes, and they map monotonically into the parameters of interest. When estimating Equation (11), I focus on the first-order difference to deal with firm-fixed effects. I use twice-lagged profit, as well as lagged and twice-lagged capital stock as instruments, and I impose a complete set of year dummies to absorb the time-series heterogeneity in the data.

\footnotetext{
${ }^{1} \rho_{z}$ and $\sigma_{z}$ are the persistence and standard deviation of a firm's match-specific shock; $\sigma_{s}$ is the standard deviation of the transitory shock; $\theta$ is the curvature of a firm's production function; $\delta$ is the depreciation rate of physical capital; $\left\{\nu_{1}, \nu_{2}\right\}$ represents the linear-quadratic cost for net equity issuance; $\kappa^{m}$ measures to what extent managers care about the firm's market value; and $c$ captures the opportunity cost for executive turnover.
} 
The next four moments are the standard deviation and $\mathrm{AR}(1)$ coefficient of a firm's investment and operating income. These four moments help to identify the standard deviations of the shock process. Keeping all else constant, an increase in both $\sigma_{s}$ and $\sigma_{z}$ will increase the variance of the investment and operating income while only an increase in $\sigma_{s}$ will affect the estimated $\operatorname{AR}(1)$ coefficients. The third set of moments includes the mean of investment, which is used to determine the depreciation rate, $\delta$, as well as the mean and variance of net equity issuance, which are used to pin down the linear-quadratic equity issuance cost $\left\{\nu_{1}, \nu_{2}\right\}$. I further add the frequency of turnover and the correlation between turnover and earnings to help identify the opportunity cost of firing, $c$. Lastly, I include the mean and standard deviation of market-to-book ratio, the mean and standard deviation of dividend payments, and the SOA of dividends. These are the "catch-all" moments in the model, but they are most sensitive to $\kappa^{m}$, which measures to what extent managers care about the firm market value.

\subsection{Main Results}

Panel A of Table 3 presents the moment conditions. The results show that the model provides a good overall fit to the data. Only two simulated moments, the standard deviation of investment and the mean market-to-book ratio, are statistically different from the corresponding actual moments at the $10 \%$ level. An over-identification test fails to reject the model with a $P$-value of 0.112 .

[Insert Table 3]

Panel B of Table 3 reports the structural parameter estimates. On the real side, a firm's production function has substantial curvature and the productivity 
shock, $\left\{z_{t}\right\}$, has a moderate degree of persistence. On the financial side, the cost for net repurchase average at $7 \%$, which is roughly the sum of gross spread and percentage discount in an SEO (Gao and Ritter, 2010).

The opportunity cost from turnover, $c$, is positive and significant, suggesting that turnover disrupts a firm's operation and induces the firm to produce at belowcapacity levels for subsequent periods. Having a significant turnover cost implies that the firm will keep its incumbent managers for most of the times. Forced turnover will be triggered only infrequently when there is substantial bad information conveyed by earnings and dividends.

I run the following Logit regression on both the actual and simulated data to examine these predictions:

$$
\operatorname{Prob}\left(\Phi_{t}=1\right)=F\left(\beta_{0}+\beta_{y} \times y_{t}+\beta_{d} \times \triangle d_{t}+\beta_{X} \times X_{t}+\epsilon_{t}\right),
$$

where $F$ is the CDF of logistic distribution, $y_{t}$ is a firm's profitability, and $d_{t}$ is the dividend payments. When the regression is run on the actual data, $X_{t}$ includes the commonly used performance and governance control variables in the executive turnover literature. When the regression is run on the simulated data, $X_{t}$ consists of the managers' optimal policies.

[Insert Table 4]

Table 4 suggests that the model consistently predicts a negative earningsdividend correlation. After controlling for earnings, dividend changes still have 
a strong predictive power for executive turnover. For firms whose current earnings are around the median, reducing dividend per share by a quarter will increase the expected rate of turnover by $15 \%$, while for firms whose earnings are around the lower 10th percentile, the increase in expected turnover will be around $29 \%$. These results stay quantitatively very similar even after I add additional controls or include higher degree polynomials of earnings. It is worth mentioning that I do not include these regression results directly in my moment matching process. However, the estimated regression coefficients on the simulated data very closely track their counterparts on the actual data. In particular, I am able to match the marginal effects of earnings and dividend changes on executive turnover. These results further support the validity of the turnover induced dividend smoothing story.

\subsection{Counterfactuals}

This section contains two counterfactual exercises. In the first case, I re-estimate an alternative model specification by shutting off the state-contingent turnover effect. The result shows qualitatively how the overall fit of the model will be affected by assuming away the agency career concern. In the second case, I resimulate data using different values for $\gamma_{d}$ to quantify the sensitivity of firm policies to the dividend informativeness.

[Insert Table 5]

Table 5 reports the estimation results for a model in which the executive turnover rate equals $2.63 \%$ at all times and in all states. Table 5 shows that the overall model fit becomes significantly worse under this constant turnover specification. In particular, the model is not able to match the variance of operating 
income, investment, and the mean market-to-book ratio. The model also fails to predict the level, and the low speed of adjustment for dividends. This is because setting turnover risk to constant will bring us back to a standard dynamic investment model with differential discount rates by the managers and the shareholders, but no agency career concern. In this case, the price effect of dividends alone is not strong enough to induce sufficient smoothing. A $J$-test suggests that the simulated moments under this alternative specification are significantly different from those on the actual data, and the model is rejected at lower than the $1 \%$ level.

An alternative way for the model to match the observed degree of dividend smoothing without relying on executives' career concern is to put higher penalty on dividend cuts. In this way, having dividend cuts will further depress the market price and affect the return to shareholders who need to trade today for liquidity reasons. Having anticipated this effect, shareholders will have a stronger preference to smooth dividends ex-ante, and managers will set payout policies to echo such preference. To examine how this alternative approach works, I first reset the cost parameter $\lambda$. Larger $\lambda$ means a higher real cost associated with dividend cuts, and it endogenously generates a stronger informational effect of dividends. As a result, an increase in $\lambda$ leads to both larger CAR around dividend announcement and inter-temporally, smoother dividend payments. I relax the constraint that the model match the observed dividend announcement effect in the data and let $\lambda$ vary freely to generate the desired the degree of dividend smoothness. Secondly, I adjust the weight matrix in my estimation. Instead of using the optimal weighting matrix, I alter it by increasing the weight corresponding to the dividend smoothness measure. This will make the SOA to be more precisely matched in the outcome. 
Table 6 confirms that this approach does lead to closer matches on the dividendrelated moments. This result is not surprising given that we are giving such moments high weights. Another point worth mentioning is that with the added degree of freedom, the overall fit of the model does not improve significantly. This is because I am twisting the optimal weighting matrix by giving the less precisely estimated moment (SOA of dividend) a higher weight. As a result, some other moments receive relatively lighter weight in the estimation process and they end up being further away from the targets. However, those moments tend to have smaller standard deviations, which means the t-statistics for the actual versus simulated moments, after scaling by the standard deviations, could be large.

[Insert Table 6]

Panel B in Table 6 shows that in order to provide a good match to the smoothness of dividends, the estimated equity issuance cost needs to be as large as $18 \%$. In addition, the return for dividend cuts will have to more than $-6 \%$. These values are different from the baseline model because in the latter setting, a turnover risk induces the managers to view dividends and earning as informational substitutes. Therefore, managers become most unwilling to increase dividends when earnings are good, due to the fact that the marginal benefit of additional good information releases is the smallest in such states. At the meantime, managers become extremely reluctant to cut dividends when earnings deteriorate in order not to reveal the persist poor economic prospects. This substitutability naturally maps into a lower responsiveness of dividends to earnings. This effect, however, can not be duplicated by simply pushing up the costs to dividend cuts. In the alternative case, the model needs to impose a huge cost on external financing and more than 
double the dividend announcement return in order to generate enough penalty for volatile dividends. The magnitudes of these fictions suggest that the model estimates are not reasonable.

To quantify to what extent managers' personal-interest determines the firmlevel dividend smoothness, I re-simulate data under several scenarios: 25\%, 50\%, and $100 \%$ decreases in $\gamma_{d}$, which captures the sensitivity between turnover and dividend changes, and 25\%,50\%, and 100\% decreases in $\lambda$, which control the dividend price effects. Setting $\gamma_{d}$ equal to zero means that the managers' choice of dividend policy does not influence their tenure, in which case, dividends will not reflect the managers' career concerns. Further forcing the values of $\lambda$ to be zero implies that dividend announcements no longer impact a firm's market prices. Hence, there is no need for the managers to smooth dividends in order to protect the value of their equity stake.

[Insert Table 7]

Table 7 shows that the smoothness of dividends (measured by 1-SOA) decreases gradually when either $\gamma_{d}$ or $\lambda$ decreases. The SOA of dividends hits 0.49 when the turnover-induced dividend smoothing incentive is removed, and it further rises to 0.95 when the announcement effect is eliminated. The speed of adjustment being close to unity indicates that shocks to a firm's cash flow get almost proportionately reflected by the firm's dividend policy. As shown in Table 7, about $62 \%$ of observed dividend smoothness is driven by the shareholders' value-maximization concern while the remaining $38 \%$ is driven by managers' self-interest. Though earnings and dividends should co-move positively due to the sources and uses of funds constraint, they act as substitutes in information production. This substitutability 
makes managers reluctant to raise dividends when earnings increase as well as to cut dividends when earnings decline, leading to a lower responsiveness of dividends to earnings. Moreover, since turnover is only a transfer of wage income from the incumbent to future managers, this type of dividend smoothing is not desirable from the shareholders' point of view. Panel B confirms this idea by further suggesting that having turnover-induced dividend smoothing reduces the equilibrium Market-to-Book ratio by $2.84 \%$. This value reduction comes from two sources. First, managers choose on average less efficient investment and financing policies to maintain dividend stability. For example, they hoard cash instead of raising dividends in cash-rich states, which leads to higher interest tax payment. They also avoid dividend cuts in low cash-flow states, which incurs the cost of issuing new equity or cutting investment. Second, dividend smoothing allows managers to withhold negative news, which implies that the realized turnover decisions will come from a more restricted information set, and they are more likely to contain errors, compared to a case where dividends fully reveal the hidden information. This effect also drives down the firm value.

\subsection{Subsample Estimations}

Although dividend smoothing is prevalent among the sample of frequent payers, there is a wide cross-sectional heterogeneity in terms of the extent to which firms smooth dividends. In this section, I am going to confront my model with the cross-sectional dispersion of dividend smoothing and examine whether it generates consistent predictions.

As a first step, I split the sample using the two-digit SIC code, and I reestimate the model based on the 17 industries with over 300 observations. Panel 
A of Figure 6 reports the simulated versus actual industry-level dividend payments under the baseline model. Panel B reports the industry estimation results assuming constant turnover risk. Figure 6 shows that the baseline model slightly undershoots the average rate of dividends, but overall, both models do a reasonable job in matching the cross-industry dispersion in dividend levels. On the other hand, the model with constant turnover risk systematically overshoots the variance of dividends. It predicts more volatile dividends than the actual data would suggest. The constant turnover risk model performs even worse when it comes to the speed of adjustment. In particular, it more than doubles the responsiveness of dividends to earnings, and it is not able to preserve the rank ordering of dividend smoothness across industries. These results sharply contrast the performance of the baseline model. Overall, Figure 6 suggests that it is important to account for managers' career concerns not only to help explain the prevalent low SOA of dividends in the data, but also to predict the wide cross-sectional dispersion of dividend smoothness among firms.

\section{[Insert Figure 6]}

Recall that, in the baseline model, the presence of turnover-induced dividend smoothing depends critically on two assumptions: First, the announced dividend policy should have a first-order effect on managers' turnover risk; second, managers should attempt to influence their turnover risk when setting the optimal firm policies. If I take these two assumptions to a cross-sectional test, it should imply that managers smooth dividends more when their turnover risk is more sensitive to dividend changes or when such risk constitutes a more important factor in their decision-making process. 
To test these predictions, I first sort firms based on the executive reputation. An executive's reputation is measured using the firm's average earnings decile from $_{\text {year }_{-2}}$ to the year when the executive first joins the firms (or to year -10 if it is sooner). If the turnover-induced dividend smoothing story is relevant, there should be less smoothing among firms run by more reputable executives. This is because such executives have accumulated good reputations by their previous success, which allows them to stay further away from the turnover threshold. Therefore, they are in better positions to "absorb" the negative news released by earnings and dividends rather than replying on dividend smoothing.

\section{[Insert Table 8]}

Table 8 reports the simulated moment conditions for the subsamples of firms sorted on executives' reputations. The results show that the model fits the data well. In particular, it closely tracks the degree of dividend smoothness in each subsample. Without this result, I will not be able to illuminate the sources of the observed dividend smoothness across subsamples using this model. Consistent with our predictions, firms with more reputable managers smooth dividends less. More specifically, such firms allow dividends to fluctuate on average by 6 percentage points $(28 \%)$ more with earnings changes, compared to their counterparts with less reputable executives. Based on the subsample estimation results, I also decompose the observed dividend smoothness into value-related and turnoverinduced following the procedures described in Section 4.3. I find that the amount of turnover-induced dividend smoothing is $16 \%$ higher among the "Low Executive Reputation" subsample, suggesting that these executives are more concerned with smoothing the information releases in order to help secure their positions. 
Table 9 splits the firms along a different dimension: the ratio of the executives' cash- versus stock-based compensation. If the top executives receive a higher fraction of stock-based compensation, it is more likely that over time, they will accumulate a larger equity stake in the firm. Therefore, they will behave similar to the equity holders and will choose a lower degree of turnover-induced dividend smoothing, which is value-destroying from the shareholders' point of view. On the other hand, if the top executives receive more cash-based compensation, they will care more about keeping their positions so as not to forfeit the future wage income. Holding all else equal, this effect implies that firms in the "Low Stock/Cash Compensation" subsample should have smoother dividends, and a larger fraction of their dividend smoothing should come from the turnover-related incentive. The results in Table 8 confirm these predictions

[Insert Table 9]

Table 10 presents the subsample results by splitting firms based on time. The "Early" subsample contains all firm-year observations prior to 2002. The "Late" subsample contains all observations from 2003 onwards. I split the sample in such a way that I have roughly the same number of years across subsamples. More importantly, there is a major tax reform in 2003 that changes the relative tax disadvantage of personal income relative to capital gains. Breaking the sample by 2003 can ensure that my estimation is not confounded by such a structural break in tax code.

[Insert Table 10] 
Table 10 suggests that over time, top executives face higher turnover risk, and they choose slightly lower and smoother dividends. However, the firms' investment opportunities and external financing frictions also change substantially over time, and hence it is very difficult to ascertain whether the two trends are correlated. To address this concern, I re-estimate the model on the two subsamples and calculate the percentage of excess dividend smoothing based on the estimated model parameters. I find that the turnover-related smoothing effect is $10 \%$ higher in the "Late" subsample. This result is consistent with our intuition that managers face more severe career concerns over time, and they react by smoothing dividends relative to earnings to make it less likely that negative information from multiple sources will be released at the same time. 


\section{Robustness}

The results discussed above are based on a simple dynamic investment model. The key friction that I consider is the inseparability between a firm's financial activities and the information production, combined with executives' career concerns. I impose a list of simplifying assumptions with respect to how a firm's investment and turnover decisions are formed to make the model tractable and estimable. In this section, I will relax the assumptions one by one to ensure that the quantitative effects based the model are not sensitive to any of these simplifications. As a preliminary step, I separate a firm's cost for issuing new equity versus the cost of conducting share repurchase. I use a simple linear function $\nu \times e_{t}$ to capture a firm's equity issuance cost and I include a fixed, as well as linear and convex costs for repurchasing shares:

$$
F\left(p_{t}\right)=f_{0}+f_{1} \times p_{t}+f_{2} \times \frac{p_{t}^{2}}{k_{t}}
$$

where $p_{t}$ stands for the dollar amount of equity issuance. Empirically, dividends and repurchases are close substitutes. I incorporate a flexible form of repurchase costs in my model to make sure that it matches the time series variation of a firm's 
repurchase activities while predicting stable dividends. Hence, the model does not generate the smoothness of dividends mechanically by shifting its volatility to the other form of cash distribution. Next, I impose more structures on the firms' investment side, I consider different types of managerial preferences, and lastly, I test under alternative assumptions about the board-manager relation. The results for the robustness tests are reported in Table 11.

[Insert Table 11]

\subsection{Lumpy Investments}

In Chapter 2, I present a simple dynamic investment model with no capital adjustment costs and perfectly reversible investments. These features do not generate the lumpiness of investments that is observed in the data. To resolve this discrepancy, I add capital adjustment costs, $A_{t}\left(i_{t}, k_{t-1}\right)$, to the model:

$$
A_{t}\left(i_{t}, k_{t-1}\right)=\alpha_{0} \times k_{t-1}+\alpha_{1} \times\left(\frac{i_{t}}{k_{t-1}}\right)^{2} \times k_{t-1}-\alpha_{2} \times\left(i_{t}\right) \times \mathbf{1}\left\{i_{t}<0\right\}
$$

which captures the fixed and convex costs of investments, as well as the asymmetry in buying and selling prices. In particular, because the cost $\alpha_{0} \times k_{t-1}$ is independent of the amount of investment, it induces optimal lumpy behavior, where the firm is inactive for long spells before investing a large amount. I resolve the model, taking the baseline parameter estimates reported in Table 3 and the adjustment cost parameter values estimated by Cooper and Haltiwanger (2006). The model with adjustment costs is able to generate investment spikes. At the meantime, the 
effect of excess dividend smoothing stays economically significant (37.45\%) even in the presence of lumpy investments.

\subsection{Stochastic Issuance Cost}

The baseline model only allows for a linear equity issuance cost. The benefit of this assumption lies in that it greatly simplifies the firms' optimal investment decision. On the downside, it predicts small but highly frequent equity issuance. Hence, one might worry that the low SOA predicted by the model could be driven by the smoothness in the firms' financing decisions. To alleviate this concern, I extend the model by incorporating a stochastic equity issuance cost. Following the idea in Eisfeldt and Muir (2012), I model a firm's ex-post equity issuance cost by $\xi_{t} \times \nu \times e_{t}$, where $\left\{\xi_{t}\right\}$ is stochastic and follows an $\operatorname{AR}(1)$ process with

a mean of 1 , autocorrelation of $\rho_{\xi}$, and unconditional variance of $\frac{\sigma_{\xi}^{2}}{1-\rho_{\xi}^{2}}$. I resolve the model, using the stochastic issuance cost parameters reported in Nikolov and Whited (2014). Table 10 suggests that imposing a linear equity issuance cost works against my story. The model predicted excess dividend smoothing increases by $5 \%$ after relaxing this assumption.

\subsection{Earnings Management}

This section deals with a case where the managers are able to smooth earnings by managing accounting accruals. Earnings management gives them an extra degree of freedom to "window dress" performance and smooth the release of negative information. I model managers' aggregate earnings management as a separate choice variable $\left\{m_{t}\right\}$. The amount of earnings management performed in the current period is denoted by $m_{t}-m_{t-1}$, which is additive to the reported earnings but has no 
real effect on the firm's sources and uses of funds constraint. Earnings management is associated with a quadratic cost $q \times\left(\frac{m_{t}}{k_{t-1}}\right)^{2} \times k_{t-1}$. This cost function captures the idea that larger earnings management over time is more likely to be detected, and hence is deemed more costly by the firm. I calibrate the earnings management cost parameter, $q$, separately by matching the average unsigned abnormal accruals calculated under the Modified Jone's Model (Dechow, Sloan, and Sweeney, 1995). Resolving the model suggests that incorporating earnings management has two opposing effects on the model-predicted dividend smoothing: 1) it suggests that a firm's earnings are more likely to reflect managerial manipulation instead of underlying economic conditions, and are hence noisier. Anticipating this effect, the shareholders will put a greater weight on the firm's dividend policy (which is more verifiable) when they forecast the productivity process. This effect induces managers to smooth dividends to a greater extent, holding all else equal. 2) Earnings management offers a separate channel to withhold negative news, which implies that the managers become less reliant on dividend smoothing, and hence they will smooth less. Table 10 suggests that the degree of excess dividend smoothing decreases slightly after allowing for earnings management, but the effect is still quantitatively large and highly significant (31.57\%). The result also confirms that managers operate on both margins (accounting accruals and dividend smoothing) in order to slow down the release of negative information and mitigate their career concerns.

\subsection{Executives' Outside Opportunities}

The baseline model does not account for the value of a managers' outside opportunity, and it implicitly assumes that upon a forced turnover, the managers' wage rate drops to zero and stays at this level thereafter. This assumption captures the 
idea that there is large rent income loss upon executives' departures, but quantitatively, it introduces an upward bias in their personal cost estimate. Eckbo, Thorburn, and Wang (2012) study executive turnover decisions for firms under financial distress. They find that $37 \%$ of the CEOs who are forced to leave office are able to find new jobs within three years. Conditional on finding full-time executive positions, the median annualized income change is $-47 \%$ among these CEOs. To check whether similar effects exist in my sample, I randomly pick 100 top executives who experience forced turnover and track their career path for the subsequent five years. Consistent with Eckbo, Thorburn, and Wang (2012), I am only able to identify 24 cases where a top executive moves on to another full-time position in a different company. The average income loss among these 24 executives is $33 \%$. In this robustness check, I use the executives' subsequent wage decreases as a measure for their rent income, which captures how much more they are able to extract above and beyond their second best options. I re-write the executives' utility as the sum of their rent income stream, plus the value of their equity stake, and I re-estimate the model. All parameter values stay quantitatively similar.

\subsection{Executives' Stock Options}

In the baseline model, I combine the executives' holdings of stocks and stock options and name the sum as their equity stake in the firm. In reality, one may worry about this grouping because executives' stock options typically do not come with dividend rights. This feature of compensation contracts imposes a personal cost of dividend distributions on the managers and makes them favor stock repurchases over dividends (Hall and Liebman, 2000). To alleviate this concern, I separate the executives' stock holdings, vested and non-vested stock options (averaging at $0.76 \%, 0.22 \%$, and $0.15 \%$ of a firm's total shares outstanding, respectively), and 
I re-estimate the model. The estimation yields parameter values roughly in line with the baseline case, except that the costs for repurchase have increased substantially. These higher costs offset the managers' reluctance to pay dividends and make the model-predicted payout levels consistent with the actual data. Despite the changes in parameter estimates, the magnitude of excess dividend smoothing stays economically significant and quantitatively similar.

\subsection{Executives' Risk Aversion}

The baseline model assumes risk neutrality for both the shareholders and the executives. This assumption is built on the idea that the top executives have sufficiently large outside wealth and can achieve good income smoothing by themselves instead of relying on the firm. In the following robustness check, I relax this assumption and consider risk-averse managers with habit formation. Managers are assumed to have exponential utility, $u_{t}=1-\frac{1}{\beta}-e^{-\beta\left(w_{t}-h \times w_{t-1}\right)}$, with the risk-aversion parameter $\beta=2$, and the habit persistence parameter $h=0.74$. I further assume that the managers do not have access to personal savings and investment opportunities, so that their per period consumption will be exactly equal to their wage income. The managers' wage income consists of a fixed salary, $\eta$, plus a bonus component, $\eta_{z} \times \hat{z}_{t}$, which is proportional to the shareholders' perceived match-specific productivity shock, $\hat{z}_{t}$. I estimate the value of $\eta_{z}$ to match the correlation between executive total salary and firm profitability. Consistent with Lambrecht and Myers $(2012,2014)$, risk-averse, habit-persistent managers tend to under-invest. As a result, firms are smaller in size, and the model calls for a larger depreciation rate to match the level of investments in the data. The managers also tend to smooth dividends excessively in order to smooth their marginal utility. This incentive explains roughly $50 \%$ of the observed dividend smoothing in the data. This result, 
combined with the one presented in the baseline model, defines the range of excess dividend smoothing in cases where the managers can smooth their income stream to some degree, but not perfectly.

\subsection{Board's Entrenchment}

It has been argued that firms' executive turnover decisions are not only determined by the degree of stock price pressure (Warner, Watts, and Wruck, 1988) or relative firm performance (Parrino, 1997), but also by the level of entrenchment established between the board members and top executives (Taylor, 2010). To examine this possibility, I follow Taylor (2010) and assume that the board faces a personal turnover cost, $c_{p}$, which is constant across time and does not depend on the firm's economic states. I further assume that the entrenched board has the same information set as the executives and can see the firm's productivity process. The board will initiate a turnover if the criterion described in Equation (9) is satisfied, or if the net benefit from turnover conditional on their information set exceeds $c_{p}$. I re-estimate the model with an entrenched board. The result confirms the idea that the board faces substantial personal cost from firing an executive. As a result, they tend to under-utilize their information and delay turnover decisions. On the other hand, having an entrenched board does not change the model-predicted excess dividend smoothing quantitatively. The managers still have strong incentives to smooth the information released by dividends based on their career concerns, and such incentive explains $37.54 \%$ of dividend smoothness in the data. 


\subsection{Asymmetric Learning Speed}

Lastly, I consider a case where the shareholders extract a different amount of information from dividend increases versus cuts. This assumption implies that the forecasting coefficient, $\gamma_{d}$ in Equation (7), can vary based on the content of the dividend announcements. Estimating this alternative model specification suggests that shareholders tend to learn more quickly when the dividend announcements convey negative information, which gives the managers very strong incentives to stay away from dividend cuts. This result is consistent with the survey evidence documented in Brav et al. (2005). Table 10 suggests that a model with asymmetric learning speed generates parameter estimates very similar to the baseline case; the results show only a slightly higher degree of excess dividend smoothing (40.78\%). I also estimate models where the learning is based on having dividend increases or declines instead of on the magnitude of the changes. The results (untabulated) are also quantitatively similar. 


\section{Conclusion}

This paper provides a framework to study the interaction of dividend smoothing, firm value, and managers' well-being. I solve and estimate a dynamic agency model in which dividends signal the firm's persistent earnings. In equilibrium, stock prices react to both earnings announcements and dividend changes, and this price reaction has a first-order effect on executive turnover. In anticipation of this effect, managers smooth dividends relative to earnings to withhold negative news and lower the risk of turnover. Because turnover is only a transfer of wage income from the incumbent to future managers, this type of dividend smoothing is considered excessive from the shareholders' point of view. Dividends would be markedly more responsive to earnings if set directly by shareholders to maximize the firm value.

The model is able to match key features of the data. First, dividend changes contain information about the firm's earnings process. Observing a dividend reduction does not directly predict future earnings declines. Rather, it suggests that extreme low earnings have already been realized and are likely to have persistent effects on future performance. This result reconciles the dividend signaling story with the empirical evidence in Watts (1973), who finds that the magnitude of fu- 
ture earnings changes predicted by current unexpected dividends is small. Second, the information embedded in dividends enters into the board's executive turnover decision. In both the actual and simulated data, the average firing rate for top executives increases by roughly one-third following dividend cuts, after controlling for other firm- and executive-level characteristics. Lastly, the model is able to generate sticky dividends. Dividends exhibit low variance and are not highly responsive to earnings changes. This feature is well-documented in the empirical corporate finance literature, but it is shared by relatively few dynamic models.

Estimating a dynamic agency model offers novel insights into the sources and consequences of dividend smoothing. In a world with agency friction, managers smooth dividends excessively to mitigate their career concerns. This channel accounts for $38 \%$ of the observed smoothness in the data, and it predicts a $2.84 \%$ firm value loss in equilibrium. However, this is not to say that such turnover-induced dividend smoothing represents an inefficiency on the firm side because we do not have a benchmark to evaluate what is the minimal contracting cost for such agency friction. Finding an answer to this question entails incorporating this channel into a dynamic contracting model, which is an interesting topic for future research. 


\section{A Numerical Solution}

This appendix illustrates how the equilibrium allocation is solved. A graphical illustration of the solution algorithm is presented in Figure A.1

\section{[Insert Figure A.1]}

The algorithm is similar to that described in Krusell and Smith (1998). As a preliminary step, I descritize the five state variables $\{z, s, k, l, d\}$. The net asset value lies between 0 and $\bar{k}$, where $\bar{k}$ is the maximum capital that a firm will hold in the first-best case. A firm's dividends lie between 0 and $(0.1 \times \bar{k})$. The shocks to a firm's productivity are transformed into discrete states using the quadrature method described in Tauchen and Hussey (1991). After defining the grid space, I solve the equilibrium allocation via the following steps: (1) I guess the shareholders' optimal forecasting rule, $\Gamma=\left\{\gamma_{0}, \gamma_{\hat{z}}, \gamma_{y}, \gamma_{\varphi}, \gamma_{\Omega}\right\}$. Taking this rule as given, I solve the managers' optimal policy, $\Omega_{t}=\left\{i_{t}, e_{t}, l_{t}, d_{t}\right\}$. In Equations (5) and (8), managers' value and the firm's stock price are interdependent, so they have to be determined simultaneously. (2) To achieve this, I first set the firm's value function to the first-best case: 


$$
V_{t}^{F B}\left(z_{t}, s_{t}, d_{t-1}, k_{t-1}, l_{t-1}\right)=\max _{\Omega_{t}}(1-\lambda) d_{t}-e_{t}-\Lambda\left(e_{t}\right)+\beta \times \mathbb{E} V_{t+1}^{F B}
$$

subject to the sources and uses of funds constraint:

$$
y_{t}-i_{t}+\tau_{c} \delta k_{t}+\left(l_{t-1}+k_{t-1}\right) \times\left[1+r_{f}\left(1-\tau_{c}\right)\right]+e_{t}-d_{t}-w_{t}-l_{t} \geq 0 .
$$

Because the model does not include any adjustment cost, I can collapse a firm's holdings of liquid assets and physical capital into a single state variable, $a_{t}$ :

$$
a_{t}=c_{t}+k_{t}-\delta k_{t} \times\left(1-\tau_{c}\right),
$$

where $a_{t}$ denotes the firm's net worth. I can rewrite Equation (A.1) and Equation (A.2) as functions of this new state variable:

$$
\begin{aligned}
& V_{t}^{F B}\left(z_{t}, s_{t}, d_{t-1}, a_{t-1}\right)=\max _{\Omega_{t}}(1-\lambda) d_{t}-e_{t}-\Lambda\left(e_{t}\right)+\beta \times \mathbb{E} V_{t+1}^{F B}, \\
& \text { s.t. } \quad y_{t}+a_{t-1} \times\left[1+r_{f}\left(1-\tau_{c}\right)\right]+e_{t}-\delta k_{t}-w_{t}-d_{t}-a_{t} \geq 0 .
\end{aligned}
$$

Conditional on $V_{t}^{m}=V_{t}^{i}=V_{t}^{F B}\left(z_{t}, s_{t}, d_{t-1}, a_{t-1}\right)$, I solve the managers' value function, $U_{t}$, using value function iteration:

$$
U_{t}\left(z_{t}, s_{t}, d_{t-1}, a_{t-1}\right)=\max _{\Omega_{t}} \mathbb{E}\left[\sum_{s \geq t}\left(\prod_{s \geq v \geq t} \beta\left(1-\Phi_{v}\right)\right) w_{t}+\kappa^{i} V_{t}^{i}+\kappa^{m} V_{t}^{m}\right]
$$


in which $\Phi_{t}$ represents the period $t$ executive turnover decision:

$$
\Phi_{t}= \begin{cases}1, & V\left(z_{t}, s_{t}, a_{t-1}, d_{t-1} \mid \hat{z}_{t}\right) \leq \underline{V}\left(a_{t-1}\right) \\ 0, & \text { otherwise }\end{cases}
$$

If the firm decides to dismiss its incumbent managers, it takes a random draw from the initial unconditional distribution: $z_{\text {new }} \sim N\left(0, \frac{\sigma_{z}^{2}}{1-\rho_{z}^{2}}\right)$ and resets: $z_{t}=$ $z_{\text {new }}-c$. Solving Equation (A.6) subject to the constraint Equation (A.5) yields the managers' optimal decision, $\Omega_{t}^{*}$. Based on this optimal decision, I can update the firm's value function:

$$
\begin{gathered}
V_{t}^{i}\left(z_{t}, s_{t}, d_{t-1}, a_{t-1}\right)=(1-\lambda) d_{t}-e_{t}-\Lambda\left(e_{t}\right)+\beta \times\left(\mathbb{E} V_{t+1}^{i}-\triangle d\right) . \\
V_{t}^{m}\left(z_{t}, s_{t}, d_{t-1}, a_{t-1}\right)=\max _{\Omega_{t}} U(1-\lambda) d_{t}-e_{t}-\Lambda\left(e_{t}\right)+\beta\left(\mathbb{E}_{z_{t}=\hat{z}_{t}} V_{t+1}^{m}-\triangle d\right),
\end{gathered}
$$

I iterate until the $\left\{U_{t}, V_{t}^{m}, V_{t}^{i}\right\}$ converges. (3) I then generate a panel of firms according to the optimal policy, $\Omega_{t}^{*}$, and I calculate what forecasting decision best describes the simulated data:

$$
\left\{\gamma_{0}^{*}, \gamma_{\tilde{z}}^{*}, \gamma_{y}^{*}, \gamma_{\varphi}^{*}, \gamma_{\Omega}^{*}\right\}=\arg \min \mathbb{E}\left[\left|\gamma_{0}+\gamma_{\hat{z}} \times \hat{z}_{t-1}+\gamma_{y} \times y_{t}+\gamma_{\varphi} \times \varphi_{t}+\gamma_{\Omega} \times \Omega_{t}-z_{t}\right|\right]
$$

Obtaining the optimal forecasting rule is essentially finding the least absolute deviation estimators in the following regression:

$$
z_{t}=\gamma_{0}+\gamma_{\hat{z}} \times \hat{z}_{t-1}+\gamma_{y} \times y_{t}+\gamma_{\varphi} \times \varphi_{t}+\gamma_{\Omega} \times \Omega_{t}+\epsilon_{t}
$$


Estimating the regression also provides a measure for the goodness-of-fit. (4) I stop if the estimation yields reasonable goodness-of-fit and the parameter values converge to the initial guess. If the parameter values have converged, but the goodness-of-fit is poor, I will add in additional determinants or try a different functional form of Equation (A.11). 


\section{B Estimation Procedure}

This appendix gives a brief outline of the estimation procedure. Let $x_{i, t}$ represent the real data vector and let $y_{i, t, s}(\beta)$ represent the simulated data, where $i=(1,2,3 \ldots n)$ denotes the number of firms, $t=(1,2,3 \ldots T)$ indicates the number of time periods, and $s=(1,2,3 \ldots S)$ represents the number of simulated datasets. I explicitly write $y_{i, t, s}$ as a function of $\beta$ to emphasize the dependence of simulated data on the deep structural parameters. Michaelides and $\mathrm{Ng}$ (2000) find that good finite-sample performance of a simulation estimator requires a simulated sample that is approximately ten times as large as the actual data sample. I set $S=10$ following their suggestion.

Equation (11) contains the first two moments in the estimation process. As Cooper and Haltiwanger (2006) argue, this equation can be derived as an auxiliary equation from the firm's production function and the profitability shock process. The detailed procedures are illustrated as follows: First, I take log of a firm's profit function,

$$
\ln y_{t}=\ln z_{t}+\ln s_{t}+\theta \times \ln k_{t}
$$


Substitute $z_{t}$ and $z_{t-1}$ with $\left(\rho \times z_{t-1}+\epsilon_{z, t}\right)$ and $\left(\ln y_{t-1}-\theta \ln k_{t-1}-\ln s_{t-1}\right)$, respectively. I can then rewrite Equation (B.1) as:

$$
\ln y_{t}=\rho \times\left(\ln y_{t-1}-\theta \ln k_{t-1}-\ln s_{t-1}+\epsilon_{z, t}\right)+\ln s_{t}+\theta \times \ln k_{t} .
$$

I rearrange terms in Equation (B.2) to get:

$$
\ln y_{t}=\rho \times \ln y_{t-1}+\theta \times \ln k_{t}-\rho \times \theta \times \ln k_{t-1}+\left(\ln s_{t-1}-\rho \times \ln s_{t-1}+\epsilon_{z, t}\right) .
$$

Equation (B.3) is in the same format as Equation (11), which can be directly estimated from the simulated data. For the actual data, I remove the firm-fixed effects by focusing on the first difference, and I include a complete set of year dummies to absorb the aggregate shocks. Following the suggestion in Cooper and Haltiwanger (2006), I estimate Equation (B.3) as a nonlinear GMM system, and I use lagged and twice-lagged capital, as well as twice-lagged profit as instruments.

I add another set of 15 moments to pin down the 9 underlying parameters: $\left\{\rho_{z}, \sigma_{z}, \sigma_{s}, \theta, \nu_{1}, \nu_{2}, \delta, \kappa^{m}, c\right\}$. The choice of moments and the corresponding parameter estimates are reported in Table 3. The model is estimated using simulated method of moments (SMM). SMM chooses the parameter values to minimize the distance between simulated moments and the corresponding actual moments. Let $m\left(x_{i, t}\right)$ and $y_{i, t, s}$ denote the moments calculated based on the real and simulated data, respectively. I can write the sample moment condition as:

$$
g\left(x_{i, t}, \beta\right)=\frac{1}{n T} \sum_{i=1, n} \sum_{t=1, T}\left[m\left(x_{i, t}\right)-\frac{1}{S} \sum_{s=1, S} m\left(y_{i, t, s}(\beta)\right)\right] .
$$


The simulated method of moment estimator $\hat{\beta}$ is then obtained by solving:

$$
\hat{\beta}=\arg \min _{\beta} g\left(x_{i, t}, \beta\right)^{\prime} \hat{W} g\left(x_{i, t}, \beta\right)
$$

in which $\hat{W}$ is a positive definite matrix that converges in probability to a deterministic positive definite matrix W. I use the inverse of the sample covariance matrix of the moments to construct $\hat{W}$. The calculation follows the influence-function approach described in Erickson and Whited (2002). The simulated method of moment estimator is asymptotically normally distributed:

$$
\hat{\beta}-\beta \rightarrow N(0, \operatorname{avar}(\hat{\beta}))
$$

Let $\Omega$ denote the variance-covariance matrix of the moment conditions, then the asymptotic variance $\operatorname{avar}(\hat{\beta})$ can be expressed as:

$$
\operatorname{avar}(\hat{\beta})=\left(1+\frac{1}{S}\right) \times\left[\frac{\partial g}{\partial \beta} W \frac{\partial g^{\prime}}{\partial \beta}\right]^{-1}\left[\frac{\partial g}{\partial \beta} W \Omega W \frac{\partial g^{\prime}}{\partial \beta}\right]\left[\frac{\partial g}{\partial \beta} W \frac{\partial g^{\prime}}{\partial \beta}\right]^{-1}
$$




\section{Bibliography}

Aharony, J. and Swary, I. Quarterly dividend and earnings announcements and stockholders' return: An empirical analysis. The Journal of Finance, 35:1-11, 1980.

Allen, F., Bernardo, A. E., and Welch, I. A theory of dividends based on tax clienteles. The Journal of Finance, 55(6):2499-2536, 2000.

Asquith, P. and Mullins, D. W. Equity issues and offering dilution. Journal of Financial Economics, 15(1):61-89, 1986.

Brav, A., Graham, J. R., Harvey, C. R., and Michaely, R. Payout policy in the 21st century. Journal of Financial Economics, 77:483-527, 2005.

Cao, M. and Wang, R. Optimal ceo compensation with search: theory and empirical evidence. The Journal of Finance, 68(5):2001-2058, 2013.

Cooper, R. and Haltiwanger, J. On the nature of capital adjustment costs. Review of Economics Studies, 73:611-633, 2006.

Corwin, S. A. The determinants of underpricing for seasoned equity offers. Journal of Finance, pages 2249-2279, 2003.

DeAngelo, H. and DeAngelo, L. Dividend policy and financial distress: An empirical investigation of troubled NYSE firms. The Journal of Finance, 45:1415-1431, 1990 . 
Dechow, P. M., Sloan, R. G., and Sweeney, A. P. Detecting earnings management. The Accounting Review, pages 193-225, 1995.

Dewenter, K. L. and Warther, V. A. Dividends, asymmetric information, and agency conflicts: evidence from a comparison of the dividend policies of Japanese and U.S. firms? The Journal of Finance, 53:879-904, 1998.

Dickinson, V., Kimmel, P., and Warfield, T. The accounting and market consequences of accelerated share repurchases. Review of Accounting Studies, 17(1): 41-71, 2012.

Easterbrook, F. H. Two agency-cost explanations of dividends. American Economic Review, 74:650-659, 1984.

Eckbo, B. E., Thorburn, K. S., and Wang, W. How costly is corporate bankruptcy for top executives? Working paper, Dartmouth College, 2012.

Eisfeldt, A. and Muir, T. Aggregate issuance and savings waves. Working paper, UCLA, 2012.

Erickson, T. and Whited, T. M. Two-step GMM estimation of the errors-invariables model using high-order moments. Econometric Theory, 18(03):776$799,2002$.

Fama, E. F. and Babiak, H. Dividend policy: An empirical analysis. Journal of the American Statistical Association, 63:1132-1161, 1968.

Fudenburg, D. and Tirole, J. A theory of income and dividend smoothing based on incumbency rents. Journal of Political Economy, 103:75-93, 1995.

Gao, X. and Ritter, J. R. The marketing of seasoned equity offerings. Journal of Financial Economics, 97(1):33-52, 2010.

Ghosh, C. and Woolridge, J. R. Stock-market reaction to growth-induced dividend cuts: Are investors myopic? Managerial and Decision Economics, 10:25-35, 1989. 
Grullon, G., Michaely, R., Shlomo, B., and Thaler, R. Dividend changes do not signal changes in future profitability. Journal of Business, 78(5):1956-1982, 2005.

Hall, B. J. and Liebman, J. B. The taxation of executive compensation. In Tax Policy and the Economy, Volume 14, pages 1-44. MIT Press, 2000.

Holmström, B. Managerial incentive problems: A dynamic perspective. The Review of Economic Studies, 66(1):169-182, 1999.

John, K. and Williams, J. Dividends, dilution, and taxes: A signalling equilibrium. Journal of finance, pages 1053-1070, 1985.

Kaplan, S. N. and Reishus, D. Outside directorships and corporate performance. Journal of Financial Economics, 27(2):389-410, 1990.

Krusell, P. and Smith, A. A., Jr. Income and wealth heterogeneity in the macroeconomy. Journal of Political Economy, 106(5):867-896, 1998.

Lambrecht, B. M. and Myers, S. C. A Lintner Model of payout and managerial rents. The Journal of Finance, 67:1761-1810, 2012.

Lambrecht, B. M. and Myers, S. C. The dynamics of investment, payout and debt. Working paper, MIT Sloan, 2014.

Leary, M. T. and Michaely, R. Determinants of dividend smoothing: Empirical evidence. Review of Financial Studies, 24:3197-3249, 2011.

Lintner, J. Distribution of incomes of corporations among dividends, retained earnings and taxes. American Economic Review, 46:93-117, 1956.

Mahmudi, H. and Pavlin, M. Corporate payout policy, cash savings, and the cost of consistency: Evidence from a structural estimation. Financial Management, $42(4): 843-874,2013$. 
Michaelides, A. and Ng, S. Estimating the rational expectations model of speculative storage: A Monte Carlo comparison of three simulation estimators. Journal of Econometrics, 96(2):231-266, 2000.

Michaely, R., Thaler, R. H., and Womack, K. L. Price reactions to dividend initiations and omissions: Overreaction or drift? The Journal of Finance, 50: 573-608, 1995.

Miller, M. H. and Modigliani, F. Dividend policy, growth, and the valuation of shares. the Journal of Business, 34(4):411-433, 1961.

Miller, M. H. and Rock, K. Dividend policy under asymmetric information. The Journal of Finance, 40(4):1031-1051, 1985.

Morellec, E., Nikolov, B., and Schürhoff, N. Corporate governance and capital structure dynamics. Journal of Finance, 67(3):803-848, 2012.

Mortensen, D. T. and Pissarides, C. A. Job creation and job destruction in the theory of unemployment. The review of economic studies, 61(3):397-415, 1994.

Nikolov, B. and Whited, T. M. Agency conflicts and cash: Estimates from a dynamic model. The Journal of Finance, 2014.

Nissim, D. and Ziv, A. Dividend changes and future profitability. The Journal of Finance, 56(6):2111-2133, 2001.

Parrino, R. CEO turnover and outside succession a cross-sectional analysis. Journal of Financial Economics, 46(2):165-197, 1997.

Parrino, R., Sias, R. W., and Starks, L. T. Voting with their feet: institutional ownership changes around forced CEO turnover. Journal of Financial Economics, 68(1):3-46, 2003.

Skinner, D. J. The evolving relation between earnings, dividends, and stock repurchases. Journal of Financial Economics, 87:582-609, 2008. 
Tauchen, G. and Hussey, R. Quadrature-based methods for obtaining approximate solutions to nonlinear asset pricing models. Econometrica: Journal of the Econometric Society, pages 371-396, 1991.

Taylor, L. A. Why are CEOs rarely fired? Evidence from structural estimation. The Journal of Finance, 65:2051-2087, 2010.

Vermaelen, T. Common stock repurchases and market signalling: An empirical study. Journal of financial economics, 9(2):139-183, 1981.

Warner, J. B., Watts, R. L., and Wruck, K. H. Stock prices and top management changes. Journal of financial Economics, 20:461-492, 1988.

Warusawitharana, M. and Whited, T. Equity market misvaluation, financing, and investment. Working Paper, University of Rochester, 2012.

Watts, R. The information content of dividends. Journal of Business, pages 191211, 1973. 
Figure 1: Timeline

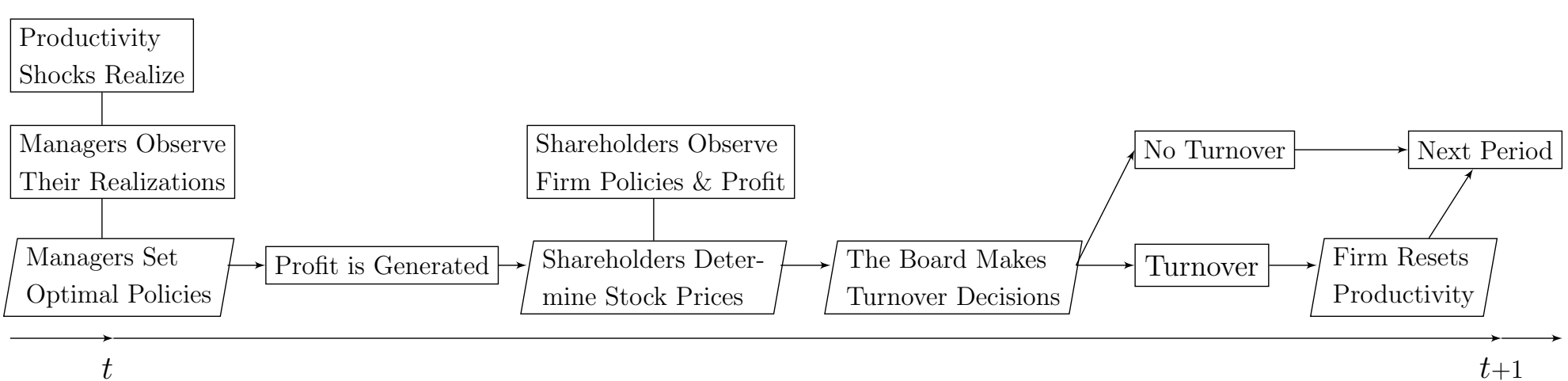

Figure 1 summarizes the timeline of the model. At the beginning of each period, the productivity shocks are realized. Managers observe their realizations and base the firm's investment, financing, and payout decisions on this information. The shareholders do not directly see the underlying productivity process. Instead, they extract information from the realized profit and the reported firm policies, and they determine the firm's market price. The board of directors is in charge of the firm's executive turnover decisions. 
Figure 2: Policy Functions
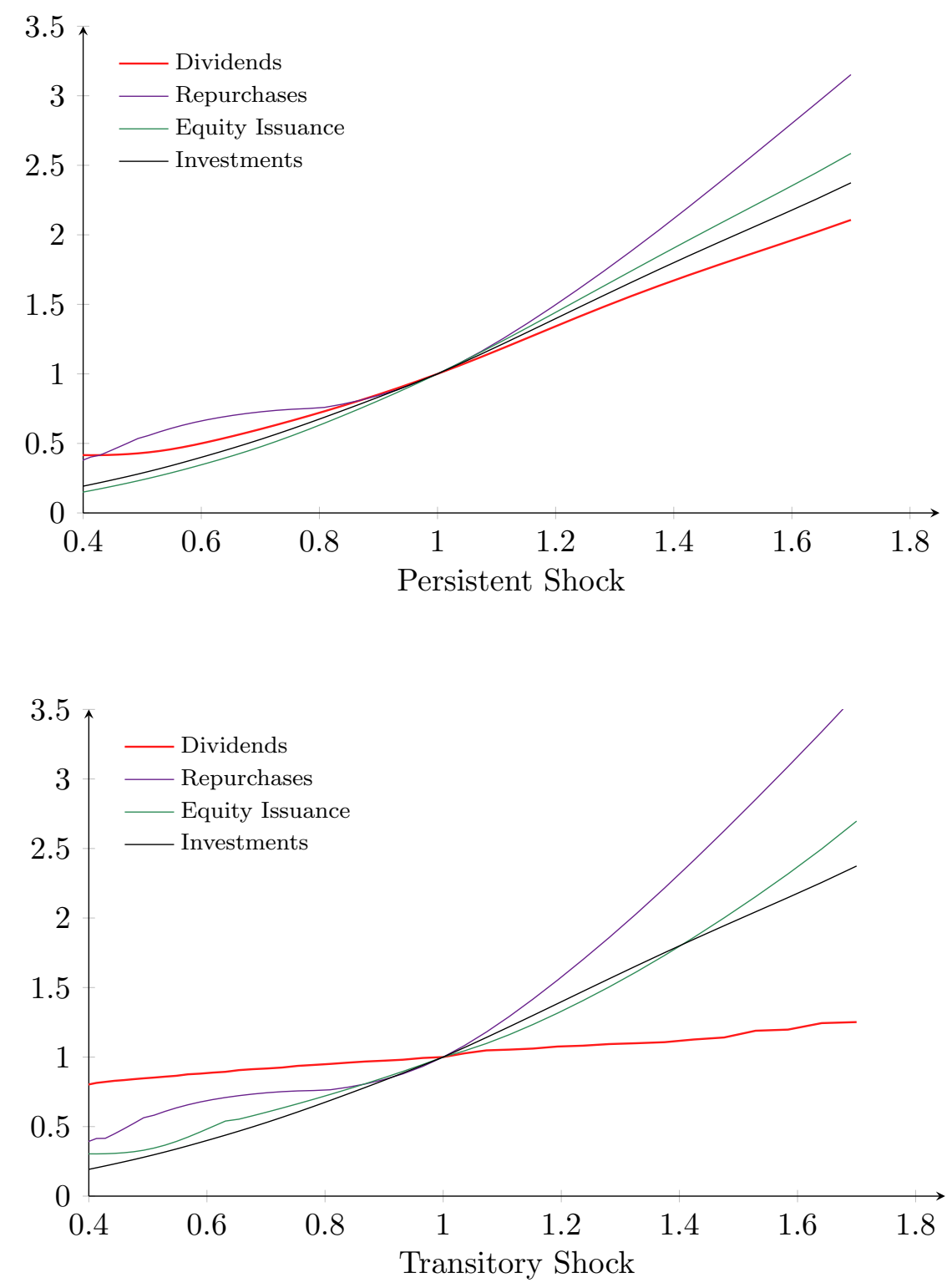

Figure 2 depicts managers' equilibrium choices of investment, equity issuance, share repurchases, and dividend payments in response to the firm's persistent versus transitory productivity shocks. The $\mathrm{x}$-axis measures the firm's productivity shocks. The y-axis indicates the firm's policies expressed as fractions of their corresponding steady state levels. 
Figure 3: The Information Content of Dividends

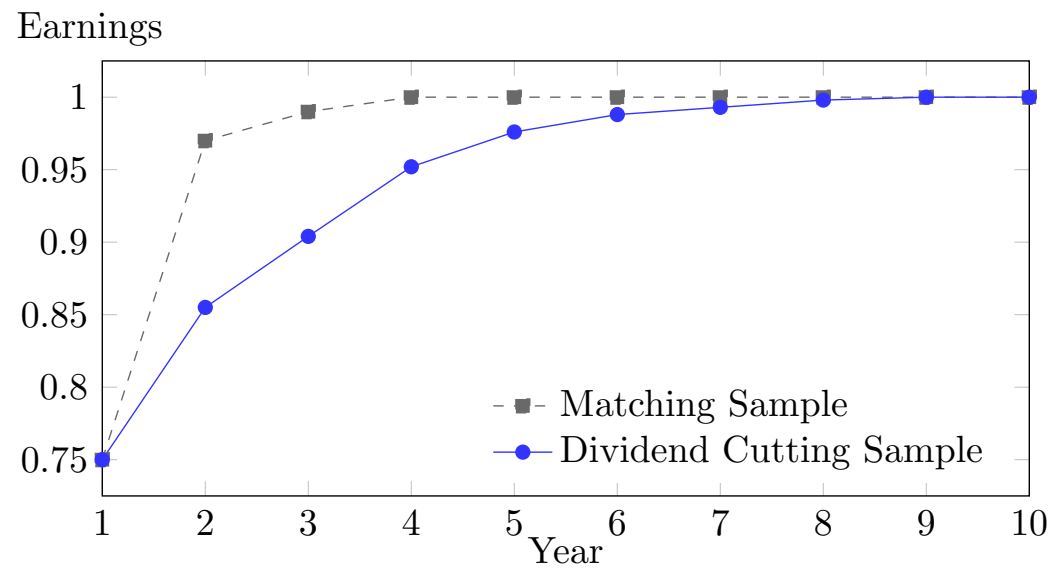

Subsequent Turnover

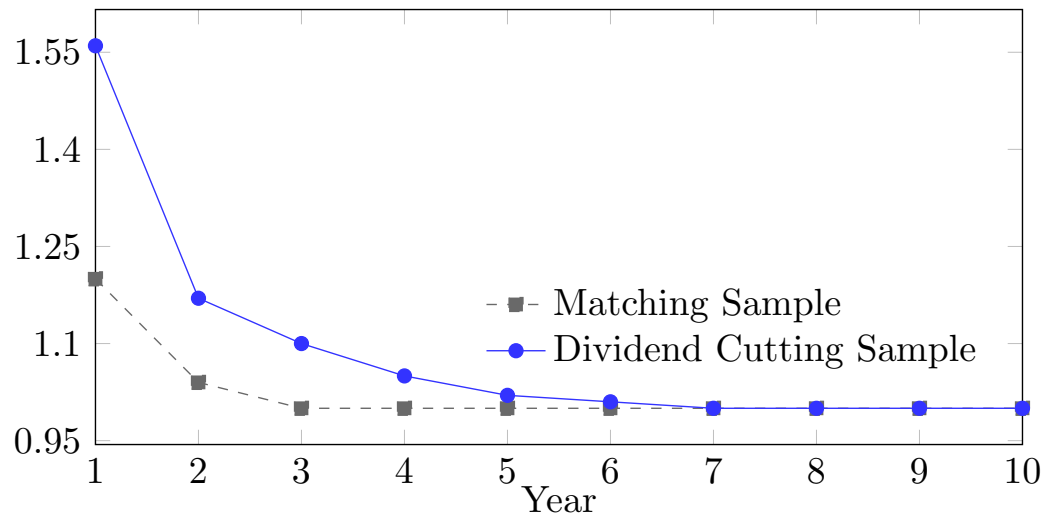

Figure 3 reports the effects of dividend cuts on the subsequent firm profit and top executive turnovers. The dividend cutting sample consists of firms who have cut dividends in year one; the matching sample is constructed from firms that have the same yearone reported earnings as the dividend cutting sample but have managed to maintain or increase dividends. Firms' profit and forced executive turnover rates are expressed as fractions of their corresponding steady state values. 
Figure 4: Managers' Career Concern and Firm Policies
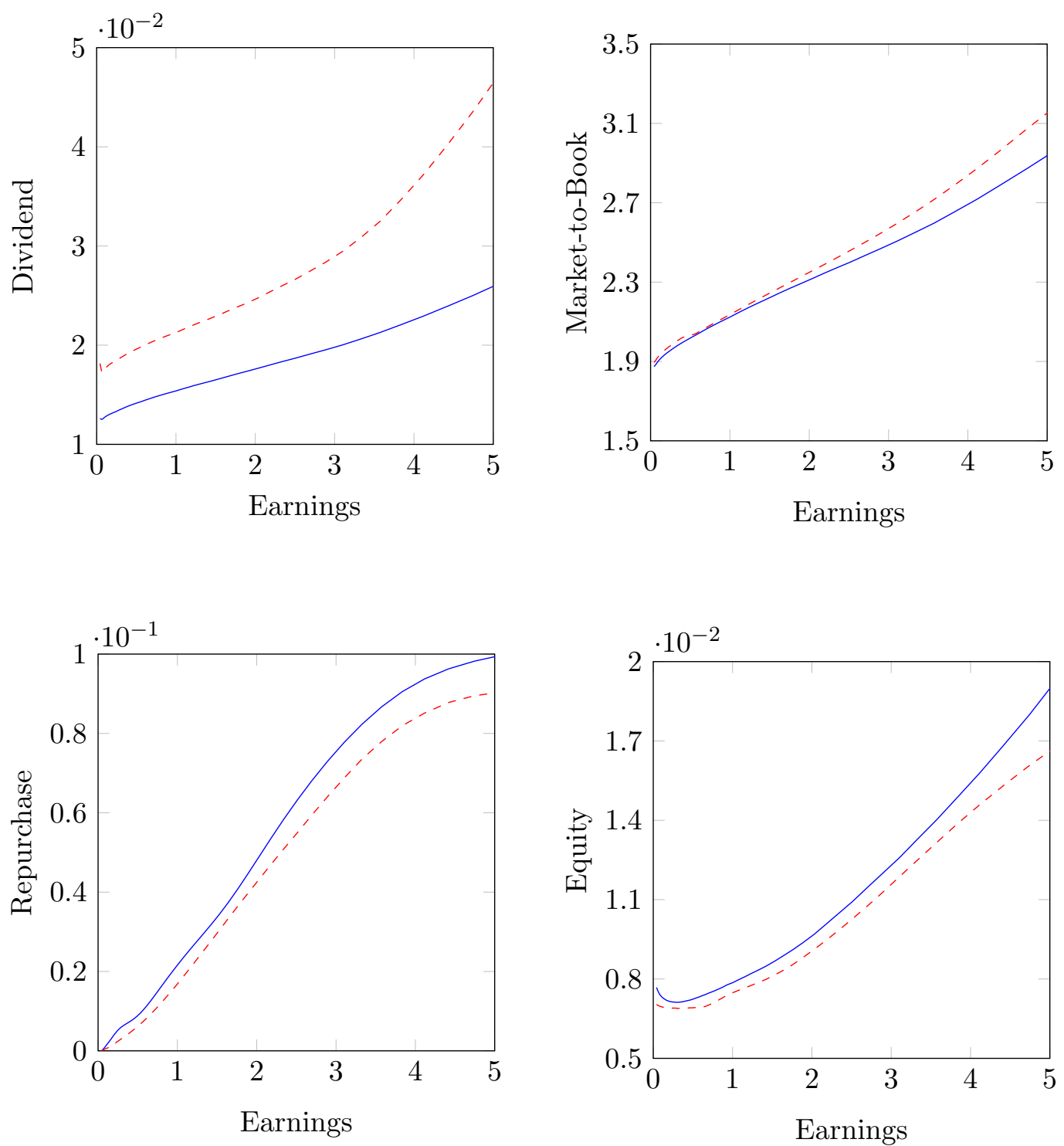

Baseline

Constant Turnover Belief

Figure 4 presents the effects of managers' career concerns on firm value and optimal policies. The figure considers two alternative model specifications: the solid line corresponds to the baseline model described in Section 2.3; the dashed line considers a case where the top managers have constant turnover belief. In each plot, earnings are normalized by their steady-state level under the constant turnover model. Firm financial policies are scaled by the firm's total asset size. 
Figure 5: Dividend Smoothing over Time

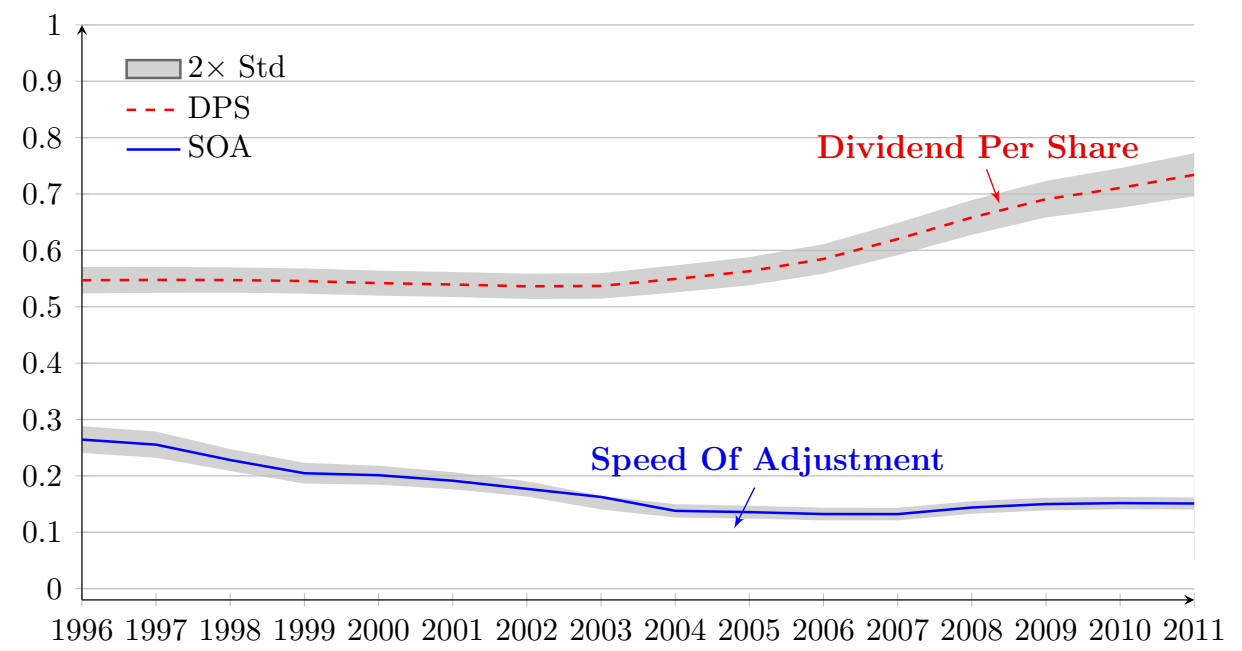

Figure 5 shows the time trend for dividend per share and dividend smoothness over the past 25 years. Dividend smoothness is measured by the speed of adjustment (SOA), which equals the estimated coefficient $\beta$ in the following regression: $D_{i, t}-D_{i, t-1}=\alpha+\beta \times\left(T P R_{i} \times E_{i, t}-D_{i, t-1}\right)+\epsilon_{i, t}$. The regression is estimated on each rolling 10-year window. $D_{i, t}$ and $E_{i, t}$ are the dividend and earnings per share, respectively. $T P R_{i}$ is a firm's target dividend payout ratio over the surrounding 10-year period. 
Figure 6: Industry Estimates

Panel A: Baseline Model
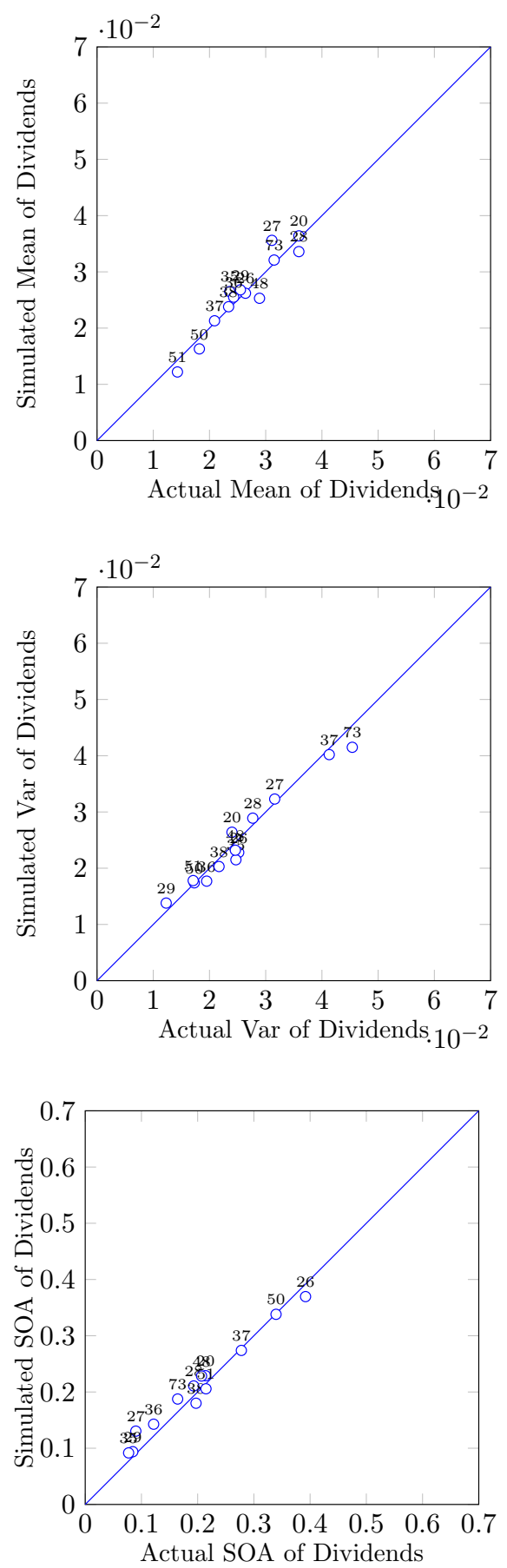

Panel B: Constant Turnover Risk Model
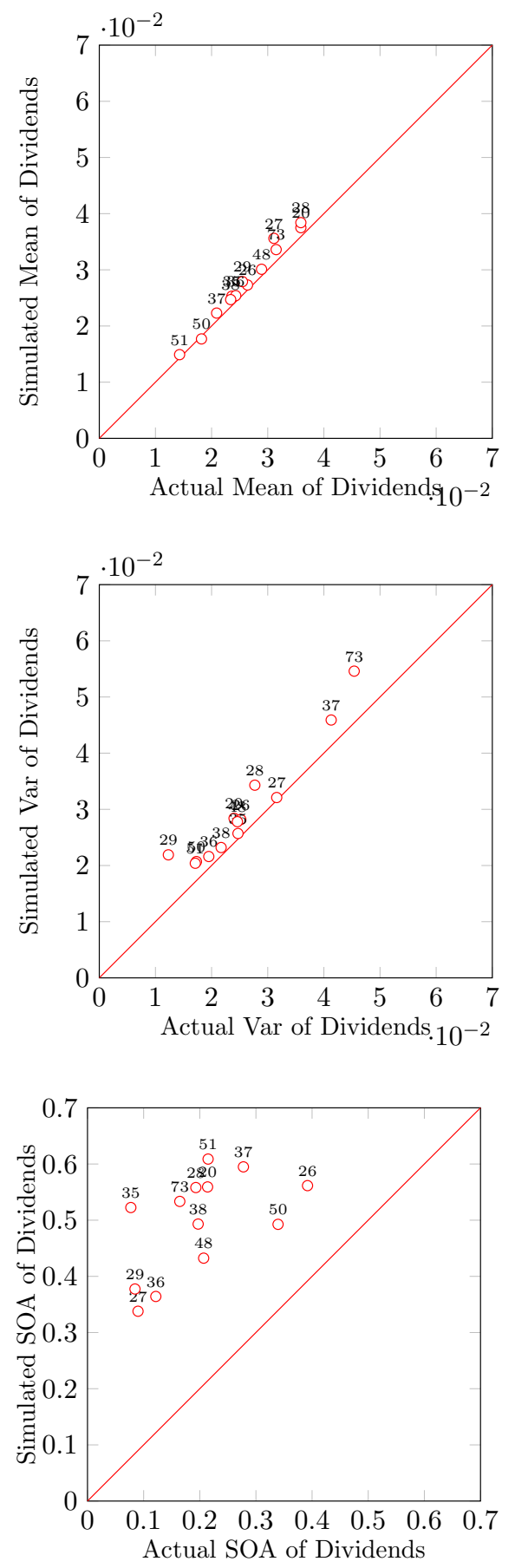

Figure 6 plots the mean, variance, and speed of adjustment for dividends in the actual versus simulated data. The sample is split into industries based on two-digit SIC codes. The model is re-estimated on the 17 industries with more than 300 firm-year observations. Panel A reports the moments under the baseline model; Panel B shows the results under a restricted model that assumes constant executive turnover rates across times and states. 
Figure A.1: Numerical Strategy

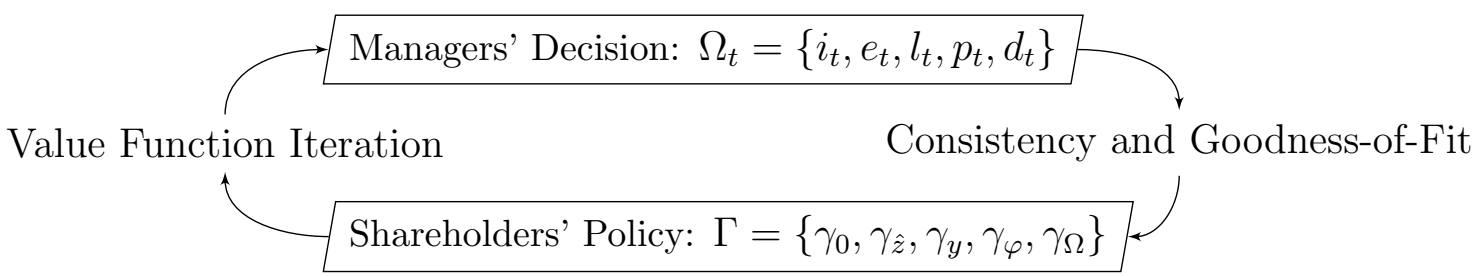

Figure A.1 illustrates how the model described in Section 2 is solved numerically. The process starts by guessing an optimal forecasting rule and assigning it to the shareholders. Taking this rule as given, managers set the optimal policies to maximize their utility. In anticipation of the managers' decision-making process, the shareholders choose the forecasting policy that best predicts the firm's underlying productivity process. 


\section{Table 1: Variable Description}

Table 1 presents the variable definitions and the parameter values used to calculate the baseline solution.

\begin{tabular}{lll}
\hline \hline Panel A: Calculated outside of the model & \\
\hline$r_{f}$ & 1-year risk-free interest rate & $2 \%$ \\
$\tau_{c}$ & Corporate income tax rate & $35 \%$ \\
$\tau_{p}$ & Personal tax rate on dividends & $15 \%$ \\
$\eta$ & Executive total compensation (\% steady state asset) & 0.0978 \\
$\kappa^{i}$ & Executives' stake in firm intrinsic value (\% shares outstanding ) & 1.1268 \\
$\lambda$ & Cost of dividend cuts & $3 \%$ \\
\hline
\end{tabular}

Panel B: Solved in equilibrium allocation

\begin{tabular}{lll}
$\left\{k_{t}\right\}$ & Stock of physical capital & $/$ \\
$\left\{l_{t}\right\}$ & Holdings of liquid assets & $/$ \\
$\left\{e_{t}\right\}$ & Net Equity issuance & $/$ \\
$\left\{d_{t}\right\}$ & Regular dividend distribution to shareholders & $/$ \\
$\left\{\hat{z}_{t}\right\}$ & Shareholders' forecasted firm productivity & $/$ \\
$\left\{\Phi_{t}\right\}$ & Dummy variable indicating forced executive turnover & $/$ \\
\hline
\end{tabular}

Panel C: Estimated within the model

\begin{tabular}{lll}
\hline$\rho_{z}$ & Persistence of firm-level productivity shock & 0.7021 \\
$\sigma_{z}$ & Standard deviation of the persistent productivity shock & 0.2926 \\
$\sigma_{s}$ & Standard deviation of the transitory shock & 0.0783 \\
$\theta$ & Curvature of a firm's production function & 0.5524 \\
$\delta$ & Capital depreciation rate & 0.0983 \\
$\nu_{1}$ & Linear External Financing Cost & 0.0663 \\
$\nu_{2}$ & Quadratic External Financing Cost & 0.7104 \\
$\kappa^{m}$ & Executives' stake in firm market value (\% shares outstanding ) & 0.6223 \\
$c$ & Opportunity cost of executive turnover & 0.4607 \\
\hline
\end{tabular}

Panel D: Sock Processes

\begin{tabular}{lll}
$\left\{\ln \left(z_{t}\right)\right\}$ & Persistent match-specific productivity shock & $\sim \rho_{z} \times \ln \left(z_{t-1}\right)+N\left(0, \sigma_{z}^{2}\right)$ \\
$\left\{\ln \left(s_{t}\right)\right\}$ & Pure transitory shock to earnings & $\sim N\left(0, \sigma_{s}^{2}\right)$ \\
$\left\{\varphi_{t}\right\}$ & Additional signal observed by shareholders & $\sim N\left(\ln \left(z_{t}\right), \frac{\sigma_{z}^{2}}{1-\rho_{z}^{2}}\right)$ \\
\hline
\end{tabular}


Table 2: Summary Statistics

The sample is constructed from the 2013 Compustat and CRSP file over the period 1992-2011. Non-financial and non-utility firms who declare at least six positive annual dividends in the surrounding 10-year window are included. This sample is merged with executive compensation data from the ExecuComp, institutional ownership data from Thomson Financial and a hand-collected dataset on top executive turnovers. This process yields 10,827 distinct firm-executive pairs and 11,626 firm-year observations.

\begin{tabular}{|c|c|c|c|c|c|}
\hline & Mean & Std & $25 \%$ & $50 \%$ & $75 \%$ \\
\hline \multicolumn{6}{|c|}{ Firm Investment and Financial Characteristics } \\
\hline Size & 8.0269 & 1.6111 & 6.8491 & 7.9384 & 9.1646 \\
\hline Operating Income & 0.1630 & 0.0790 & 0.1091 & 0.1490 & 0.2067 \\
\hline Leverage & 0.2542 & 0.1427 & 0.1510 & 0.2597 & 0.3546 \\
\hline Market-to-Book & 2.7443 & 2.4076 & 1.3271 & 2.0057 & 3.1630 \\
\hline Cash & 0.0707 & 0.0911 & 0.0120 & 0.0339 & 0.0906 \\
\hline Equity Issuance & 0.0105 & 0.0198 & 0.0005 & 0.0038 & 0.0105 \\
\hline Investment & 0.0985 & 0.0684 & 0.0591 & 0.0796 & 0.1256 \\
\hline Dividend & 0.0240 & 0.0179 & 0.0114 & 0.0198 & 0.0311 \\
\hline Repurchase & 0.0228 & 0.0398 & 0.0000 & 0.0028 & 0.0276 \\
\hline Dividend to Earnings Ratio & 0.1542 & 0.0984 & 0.0813 & 0.1399 & 0.2094 \\
\hline Dividend per Share & 0.6581 & 0.5930 & 0.2141 & 0.4797 & 0.9133 \\
\hline Earnings per Share & 4.5869 & 3.8815 & 2.0428 & 3.5942 & 5.8738 \\
\hline Return & 0.1226 & 0.4556 & -0.1040 & 0.0820 & 0.2775 \\
\hline \multicolumn{6}{|l|}{ Managerial Characteristics } \\
\hline Salary & 0.0251 & 0.0317 & 0.0050 & 0.0133 & 0.0318 \\
\hline Bonus & 0.0129 & 0.0211 & 0.0010 & 0.0053 & 0.0150 \\
\hline Total Compensation & 0.0735 & 0.0981 & 0.0173 & 0.0399 & 0.0864 \\
\hline \% Stock Holdings & 0.6041 & 1.5196 & 0.0318 & 0.0909 & 0.3124 \\
\hline$\%$ Vested Options & 0.1826 & 0.2169 & 0.0364 & 0.1067 & 0.2467 \\
\hline$\%$ Unvested Options & 0.1327 & 0.1682 & 0.0224 & 0.0762 & 0.1708 \\
\hline Tenure & 8.9538 & 10.8480 & 3 & 9 & 12 \\
\hline \multicolumn{6}{|c|}{ Corporate Governance Characteristics } \\
\hline Institutional Holdings & 0.6071 & 0.2103 & 0.4639 & 0.6255 & 0.7619 \\
\hline Insider Holdings & 0.0375 & 0.0115 & 0.0015 & 0.0035 & 0.0079 \\
\hline Forced Turnover Rate & 0.0263 & 0.1601 & 0 & 0 & 0 \\
\hline Abnormal Accrual & 0.0641 & 0.0768 & 0.0252 & 0.0526 & 0.0992 \\
\hline
\end{tabular}


Table 3: Simulated Moments Estimation: Full Sample

The sample consists of non-financial and non-utility firms in the 2013 Compustat and CRSP file over the period 1992-2011. The sample contains 10,827 distinct firm-executive pairs and 11,626 firm-year observations. The estimation is done with simulated method of moments (SMM), which chooses structural parameters by matching the moments from a simulated panel of firms to the corresponding moments from the data. Panel A reports the simulated versus the actual moments and the $t$-statistics for the differences. The $J$-statistic tests the over-identification constraint for the moment conditions. Panel $\mathrm{B}$ reports the parameter estimates with clustered standard errors in parentheses. $\rho_{z}, \sigma_{z}$ and $\sigma_{s}$ govern the persistence and standard deviation of firms' shock process. $\theta$ is the curvature of firms' production function. $\delta$ is the rate of depreciation. $\left\{\nu_{1}, \nu_{2}\right\}$ represents the linear-quadratic cost for net equity issuance. $\kappa^{m}$ measures by what extent managers care about the firm's market price. and $c$ captures the opportunity cost for executive turnover.

\begin{tabular}{|c|c|c|c|c|c|c|c|c|}
\hline \multicolumn{9}{|c|}{ Panel A: Moments } \\
\hline \multirow{2}{*}{\multicolumn{3}{|c|}{ Coefficient $\gamma_{y}$ in Equation (11) }} & Actu & ial Moments & Simula & ed Moments & T-test & for Difference \\
\hline & & & & 0.6514 & & 7151 & & -0.7730 \\
\hline \multicolumn{3}{|c|}{ Coefficient $\gamma_{k}$ in Equation (11) } & & 0.5404 & & 5513 & & -0.1614 \\
\hline \multicolumn{3}{|c|}{ Mean of Operating Income } & & 0.1630 & & 1720 & & -1.2822 \\
\hline \multicolumn{3}{|c|}{ Std of Operating Income } & & 0.0738 & & 0835 & & -1.6086 \\
\hline \multicolumn{4}{|c|}{ AR(1) Coefficient of Operating Income } & 0.6368 & & 6870 & & -0.7777 \\
\hline \multicolumn{4}{|c|}{ Mean of Investment } & 0.0985 & & 0996 & & -0.1667 \\
\hline \multicolumn{4}{|c|}{ Std of Investment } & 0.0645 & & .0802 & & -2.2432 \\
\hline \multicolumn{4}{|c|}{ AR(1) Coefficient of Investment } & 0.6149 & & 6207 & & -0.1612 \\
\hline \multicolumn{3}{|c|}{ Mean of Net Equity Issuance } & & -0.0185 & & .0197 & & 0.2446 \\
\hline \multicolumn{3}{|c|}{ Std of Net Equity Issuance } & & 0.0171 & & 0185 & & -0.1663 \\
\hline \multicolumn{3}{|c|}{ Mean of Market-too-Book } & & 2.7443 & & 1835 & & -2.4331 \\
\hline \multicolumn{3}{|c|}{ Std of Market-to-Book } & & 2.2892 & & 4050 & & -0.8010 \\
\hline \multicolumn{3}{|c|}{ Mean of Dividend } & & 0.0240 & & .0243 & & -0.2755 \\
\hline \multicolumn{3}{|c|}{ Std of Dividend } & & 0.0102 & & 0110 & & -0.0719 \\
\hline \multicolumn{3}{|c|}{ SOA of Dividend } & & 0.2040 & & 2047 & & -0.0151 \\
\hline \multicolumn{3}{|c|}{ Mean Turnover } & & 0.0263 & & 0275 & & -0.8009 \\
\hline \multirow{2}{*}{\multicolumn{3}{|c|}{ Corr btw Return and Turnover }} & & -0.0674 & & .0717 & & 0.2256 \\
\hline & & & & & J-stat & stics:13.21 & & val : 0.112 \\
\hline \multicolumn{9}{|c|}{ Panel B: Parameter Estimates } \\
\hline$\rho_{z}$ & $\sigma_{z}$ & $\sigma_{s}$ & $\theta$ & $\delta$ & $\nu_{1}$ & $\nu_{2}$ & $\kappa^{m}$ & $c$ \\
\hline 0.7021 & 0.2926 & 0.0783 & 0.5524 & 0.0983 & 0.0663 & 0.7104 & 0.6223 & 0.4607 \\
\hline$(0.0941)$ & $(0.0034)$ & $(0.0162)$ & $(0.1284)$ & $(0.0100)$ & $(0.0271)$ & $(0.1063)$ & $(0.1476)$ & $(0.0587)$ \\
\hline
\end{tabular}




\section{Table 4: Predicting Forced Turnover}

The sample consists of non-financial and non-utility firms in the 2013 Compustat and CRSP file over the period 1992-2011. The sample contains 10,827 distinct firm-executive pairs and 11,626 firm-year observations. Table 4 reports the coefficient estimates from the logit regression: $\operatorname{Prob}\left(\Phi_{t}=1\right)=F\left(\beta_{0}+\beta_{y} \times y_{t}+\beta_{d} \times \Delta d_{t}+\beta_{X} \times X_{i, t}+\epsilon_{i, t}\right)$. When the regression is run on the actual data, $X_{t}$ includes the commonly used performance and governance control variables in the executive turnover literature. When the regression is run on the simulated data, $X_{t}$ consists of the managers' optimal policies. $\%$ Institution is the firm-level institutional holdings; \% Insider is the firm-level aggregate insider holding; \% Executive is the executive-level holding of the firm's own stocks. The economic significance of a predictor is reported in brackets, which is defined as the probability effect if the predictor increases from the lower to the upper 10th percentile of its distribution. The significance levels in column (1)-(4) are calculated based on standard errors clustered by industry and year. The significance levels in column (5) and (6) are calculated using bootstrapped standard errors.

\begin{tabular}{|c|c|c|c|c|c|c|}
\hline & \multicolumn{4}{|c|}{ Actual Data } & \multicolumn{2}{|c|}{ Simulated Data } \\
\hline & $(1)$ & $(2)$ & $(3)$ & $(4)$ & $(5)$ & $(6)$ \\
\hline Intercept & $-3.947^{* * *}$ & $-4.428^{* * *}$ & $-4.289^{* * *}$ & $-4.428^{* * *}$ & $-3.691^{* * *}$ & $-3.442^{* * *}$ \\
\hline Profit & $\begin{array}{l}-3.540^{* * *} \\
{[-0.609]}\end{array}$ & $\begin{array}{l}-3.502^{* * *} \\
{[-0.602]}\end{array}$ & $\begin{array}{l}-3.556^{* * *} \\
{[-0.612]}\end{array}$ & $\begin{array}{l}-3.502^{* * *} \\
{[-0.602]}\end{array}$ & $\begin{array}{l}-3.445^{* * *} \\
{[-0.591]}\end{array}$ & $\begin{array}{l}-2.871^{* * *} \\
{[-0.484]}\end{array}$ \\
\hline$\triangle \mathrm{DPS}$ & $\begin{array}{l}-0.543^{* *} \\
{[-0.423]}\end{array}$ & $\begin{array}{l}-0.650^{* * *} \\
{[-0.514]}\end{array}$ & $\begin{array}{l}-0.631^{* * *} \\
{[-0.498]}\end{array}$ & $\begin{array}{l}-0.667^{* * *} \\
{[-0.529]}\end{array}$ & $\begin{array}{l}-0.743^{* * *} \\
{[-0.595]}\end{array}$ & $\begin{array}{l}-0.547^{* * *} \\
{[-0.427]}\end{array}$ \\
\hline Investment & & & & & & $\begin{array}{c}-0.053 \\
{[-0.014]}\end{array}$ \\
\hline Net Repurchase & & & & & & $\begin{array}{l}-0.726^{* * *} \\
{[-0.057]}\end{array}$ \\
\hline Size & & $\begin{array}{l}-0.017 \\
{[-0.134]}\end{array}$ & $\begin{array}{l}0.004 \\
{[0.028]}\end{array}$ & $\begin{array}{l}0.005 \\
{[0.042]}\end{array}$ & & \\
\hline Profit $_{-1}$ & & $\begin{array}{l}0.304 \\
{[0.047]}\end{array}$ & $\begin{array}{l}0.397 \\
{[0.061]}\end{array}$ & $\begin{array}{l}0.743^{*} \\
{[0.113]}\end{array}$ & & \\
\hline Profit $_{-2}$ & & $\begin{array}{l}-1.095^{* * *} \\
{[-0.175]}\end{array}$ & $\begin{array}{l}-0.829^{* *} \\
{[-0.132]}\end{array}$ & $\begin{array}{l}0.261 \\
{[0.040]}\end{array}$ & & \\
\hline Tenure & & & $\begin{array}{l}-0.032^{* * *} \\
{[-0.552]}\end{array}$ & $\begin{array}{l}-0.033^{* * *} \\
{[-0.562]}\end{array}$ & & \\
\hline$\%$ Institution & & & $\begin{array}{l}0.758^{* * *} \\
{[0.529]}\end{array}$ & $\begin{array}{l}0.842^{* * *} \\
{[0.581]}\end{array}$ & & \\
\hline$\%$ Insider & & & $\begin{array}{l}0.246^{* *} \\
{[0.094]}\end{array}$ & $\begin{array}{l}0.174^{*} \\
{[0.067]}\end{array}$ & & \\
\hline \% Executive & & & $\begin{array}{l}-0.078^{*} \\
{[-0.682]}\end{array}$ & $\begin{array}{l}-0.077^{*} \\
{[-0.667]}\end{array}$ & & \\
\hline SIC/Year FE & $\mathrm{N}$ & $\mathrm{N}$ & $\mathrm{N}$ & $\mathrm{Y}$ & $\mathrm{N}$ & $\mathrm{N}$ \\
\hline
\end{tabular}

${ }^{*},{ }^{* *}$, and ${ }^{* * *}$ indicate statistical significance at the $10 \%, 5 \%$, and $1 \%$ levels, respectively. 
Table 5: Simulated Moments Estimation: No Agency Career Concern

The sample consists of non-financial and non-utility firms in the 2013 Compustat and CRSP file over the period 1992-2011. The sample contains 10,827 distinct firm-executive pairs and 11,626 firm-year observations. This table considers an alternative model where executives are assumed to face constant turnover rates across all times and states. Panel A reports the simulated versus the actual moments and the $t$-statistics for the differences. The $J$-statistic tests the over-identification constraint for the moment conditions (excluding the last two moments). Panel B reports the parameter estimates with clustered standard errors in parentheses. $\rho_{z}, \sigma_{z}$ and $\sigma_{s}$ govern the persistence and standard deviation of firms' shock process. $\theta$ is the curvature of firms' production function. $\left\{\nu_{1}, \nu_{2}\right\}$ represents the linear-quadratic cost for net equity issuance. $\kappa^{m}$ measures by what extent managers care about the firm's market price. and $c$ captures the opportunity cost for executive turnover.

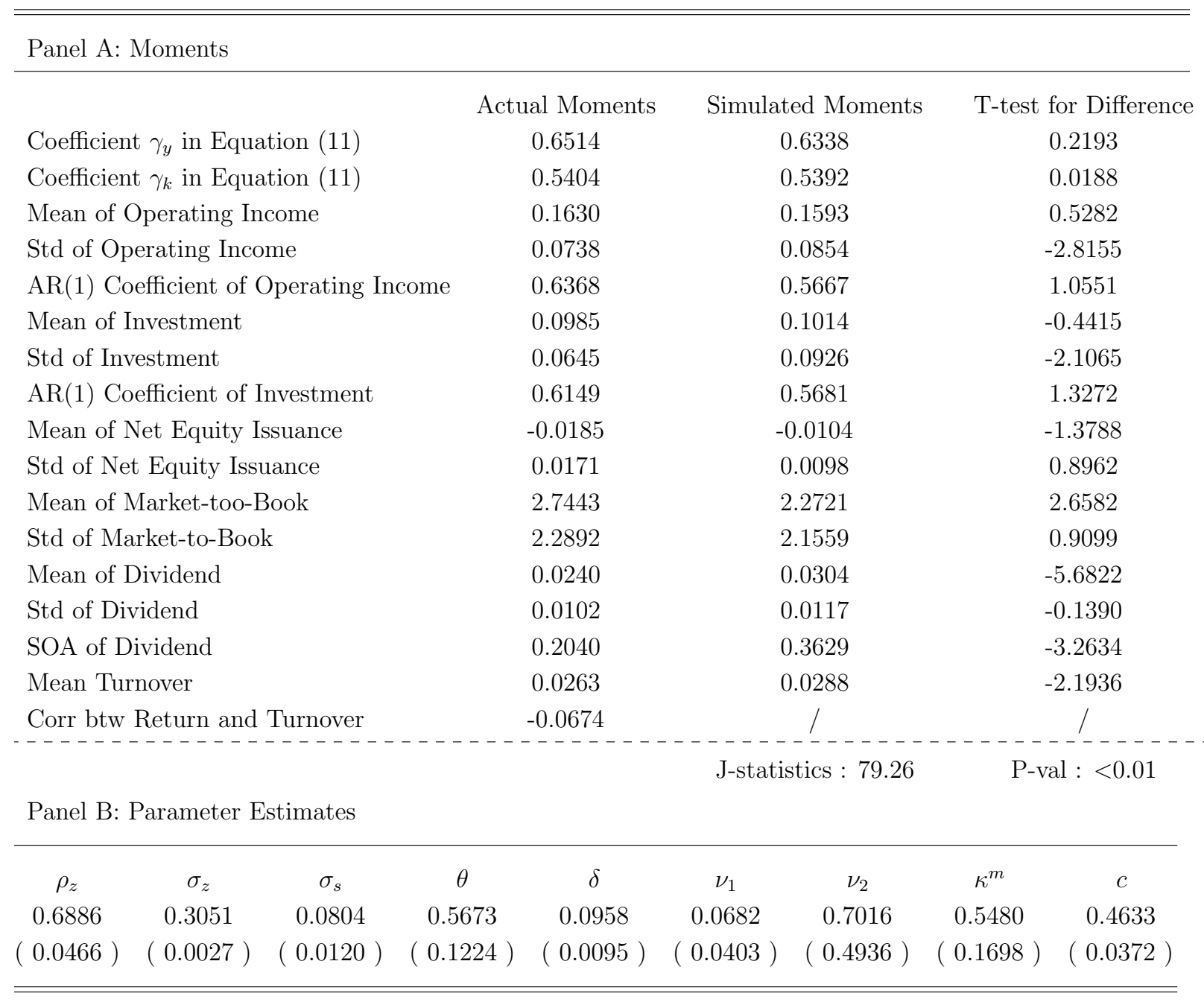


Table 6: Simulated Moments Estimation with Alternative Weight Matrix

The sample consists of non-financial and non-utility firms in the 2013 Compustat and CRSP file over the period 1992-2011. The sample contains 10,827 distinct firm-executive pairs and 11,626 firm-year observations. This table considers an alternative model where executives are assumed to face constant turnover rates across all times and states. This table alters the optimal weight matrix by increasing the weight correponding to the smoothness of dividends. Panel A reports the simulated versus the actual moments and the $t$-statistics for the differences. The $J$-statistic tests the over-identification constraint for the moment conditions (excluding the last two moments). Panel B reports the parameter estimates with clustered standard errors in parentheses. $\rho_{z}, \sigma_{z}$ and $\sigma_{s}$ govern the persistence and standard deviation of firms' shock process. $\theta$ is the curvature of firms' production function. $\left\{\nu_{1}, \nu_{2}\right\}$ represents the linear-quadratic cost for net equity issuance. $\kappa^{m}$ measures by what extent managers care about the firm's market price. and $c$ captures the opportunity cost for executive turnover.

\begin{tabular}{|c|c|c|c|c|c|c|c|c|}
\hline \multicolumn{9}{|c|}{ Panel A: Moments } \\
\hline \multicolumn{5}{|c|}{ Actual Moments } & Simulat & ted Moments & T-test & for Difference \\
\hline \multicolumn{3}{|c|}{ Coefficient $\gamma_{y}$ in Equation (11) } & & 0.6514 & & 0.6538 & & -0.0288 \\
\hline \multicolumn{3}{|c|}{ Coefficient $\gamma_{k}$ in Equation (11) } & & 0.5404 & & 0.5954 & & -0.8233 \\
\hline \multicolumn{3}{|c|}{ Mean of Operating Income } & & 0.1630 & & 0.1354 & & 3.9744 \\
\hline \multicolumn{3}{|c|}{ Std of Operating Income } & & 0.0738 & & 0.0656 & & 0.7108 \\
\hline \multicolumn{4}{|c|}{$\mathrm{AR}(1)$ Coefficient of Operating Income } & 0.6368 & & 0.5198 & & 1.8046 \\
\hline \multicolumn{4}{|c|}{ Mean of Investment } & 0.0985 & & 0.0980 & & 0.0771 \\
\hline \multicolumn{4}{|c|}{ Std of Investment } & 0.0645 & & 0.0755 & & -1.5692 \\
\hline \multicolumn{4}{|c|}{$\mathrm{AR}(1)$ Coefficient of Investment } & 0.6149 & & 0.7169 & & -2.6897 \\
\hline \multicolumn{4}{|c|}{ Mean of Net Equity Issuance } & -0.0185 & & -0.0043 & & -2.7617 \\
\hline \multicolumn{4}{|c|}{ Std of Net Equity Issuance } & 0.0171 & & 0.0095 & & 0.8610 \\
\hline \multicolumn{4}{|c|}{ Mean of Market-too-Book } & 2.7443 & & 2.1684 & & 3.0685 \\
\hline \multicolumn{4}{|c|}{ Std of Market-to-Book } & 2.2892 & & 2.4484 & & -1.1564 \\
\hline \multicolumn{4}{|c|}{ Mean of Dividend } & 0.0240 & & 0.0256 & & -1.3254 \\
\hline \multicolumn{4}{|c|}{ Std of Dividend } & 0.0102 & & 0.0109 & & -0.0701 \\
\hline \multicolumn{4}{|c|}{ SOA of Dividend } & 0.2040 & & 0.2040 & & -0.0001 \\
\hline \multicolumn{4}{|c|}{ Mean Turnover } & 0.0263 & & 0.0205 & & 3.7404 \\
\hline Corr btw & Return and & Turnover & & -0.0674 & J-stati & $\begin{array}{c}/ \\
\text { istics : } 65.77\end{array}$ & $\begin{array}{r}----- \\
P-V\end{array}$ & $\begin{array}{c}/ \\
\text { val }:<0.01\end{array}$ \\
\hline \multicolumn{9}{|c|}{ Panel B: Parameter Estimates } \\
\hline \multirow{3}{*}{$\begin{array}{c}\rho_{z} \\
0.6490 \\
(0.0403)\end{array}$} & $\sigma_{z}$ & $\sigma_{s}$ & $\theta$ & $\delta$ & $\nu_{1}$ & $\nu_{2}$ & $\kappa^{m}$ & $c$ \\
\hline & 0.2615 & 0.0703 & 0.4210 & 0.0863 & 0.1384 & 0.6037 & 0.4934 & 0.4182 \\
\hline & $(0.0032)$ & $(0.0116)$ & $(0.0895)$ & $(0.0083)$ & $(0.1042)$ & $(0.3951)$ & $(0.1665)$ & $(0.0539)$ \\
\hline
\end{tabular}


Table 7: Counterfactuals

Table 7 reports the model-predicted equilibrium firm value and dividend smoothness under different parameterizations, where $\gamma_{d}$ captures the effect of dividend changes on subsequent executive turnover risk. $\lambda$ measure the market reactions to dividend cuts. $\widehat{\gamma}_{d}, \widehat{\lambda}$ correspond to the baseline parameter estimates reported in Table 3. Equilibrium firm value is captured by the market-to-book ratio. Dividend smoothness is measured using the speed of adjustment (SOA). A larger SOA implies a lower degree of dividend smoothness.

Panel A: Dividend Smoothness

\begin{tabular}{lrrr}
\hline & SOA & Total Difference (\%) & Incremental Difference (\%) \\
\hline (1) Baseline & 0.2047 & $/$ & $/$ \\
(2) $25 \%$ decrease in $\widehat{\gamma}_{d}$ & 0.2350 & $4.06 \%$ & $4.06 \%$ \\
(3) $50 \%$ decrease in $\widehat{\gamma}_{d}$ & 0.4235 & $29.28 \%$ & $25.22 \%$ \\
(4) $100 \%$ decrease in $\widehat{\gamma}_{d}$ & 0.4920 & $38.45 \%$ & $9.17 \%$ \\
(5) $25 \%$ decrease in $\widehat{\lambda}$ & 0.7928 & $78.69 \%$ & $40.24 \%$ \\
(6) $50 \%$ decrease in $\widehat{\lambda}$ & 0.8890 & $91.56 \%$ & $12.87 \%$ \\
(7) $100 \%$ decrease in $\widehat{\lambda}$ & 0.9520 & $100.00 \%$ & $8.44 \%$ \\
\hline \hline
\end{tabular}

Panel B: Equilibrium Firm Value

\begin{tabular}{lrrr}
\hline & Firm Value & Total Difference (\%) & Incremental Difference (\%) \\
\hline (1) Baseline & 3.1835 & $/$ & $/$ \\
(2) $25 \%$ decrease in $\widehat{\gamma}_{d}$ & 3.2207 & $1.17 \%$ & $1.48 \%$ \\
(3) $50 \%$ decrease in $\widehat{\gamma}_{d}$ & 3.2376 & $1.70 \%$ & $0.53 \%$ \\
(4) $100 \%$ decrease in $\widehat{\gamma}_{d}$ & 3.2739 & $2.84 \%$ & $1.14 \%$ \\
(5) $25 \%$ decrease in $\hat{\lambda}$ & 3.3477 & $5.16 \%$ & $2.32 \%$ \\
(6) $50 \%$ decrease in $\widehat{\lambda}$ & 3.4259 & $7.61 \%$ & $2.46 \%$ \\
(7) $100 \%$ decrease in $\widehat{\lambda}$ & 3.4480 & $8.31 \%$ & $0.69 \%$ \\
\hline
\end{tabular}


Table 8: Subsample Estimation: Executive with High versus Low Reputation

Table 8 presents the subsample estimation results obtained by splitting firms based on the executives' reputation. The sample consists of non-financial and non-utility firms in the 2013 Compustat and CRSP file over the period 1992-2011. The estimation is done with simulated method of moments (SMM), which chooses structural parameters by matching the moments from a simulated panel of firms to the corresponding moments from the actual data. An executive's reputation is measured by the firm's average earnings decile from year -2 to the year when the executive first joins the firms (or to year $_{-10}$ if it is sooner). The "High Executive Reputation" subsample consists of the one-third of firms with on average more reputable executives. The "Low Executive Reputation" subsample consists of the one-third of firms with on average less reputable executives.

\begin{tabular}{lcccccc}
\hline \hline & \multicolumn{3}{c}{ High Executive Reputation } & \multicolumn{2}{c}{ Low Executive Reputation } \\
\hline & Actual & Simulated & $T$-stat & Actual & Simulated & $T$-stat \\
Coefficient $\gamma_{y}$ in Equation (11) & 0.6739 & 0.6474 & 0.2316 & 0.7369 & 0.7114 & 0.1886 \\
Coefficient $\gamma_{k}$ in Equation (11) & 0.6885 & 0.7002 & -0.1489 & 0.4689 & 0.5511 & -1.0756 \\
Mean of Operating Income & 0.1357 & 0.1173 & 2.2048 & 0.1693 & 0.1641 & 0.5294 \\
Std of Operating Income & 0.0635 & 0.0886 & -2.3728 & 0.0618 & 0.0782 & -1.5803 \\
AR(1) Coefficient of Operating Income & 0.6754 & 0.6301 & 0.6198 & 0.6940 & 0.6442 & 0.5106 \\
Mean of Investment & 0.0480 & 0.0407 & 0.7595 & 0.1699 & 0.1699 & -0.0042 \\
Std of Investment & 0.0384 & 0.0423 & -0.3607 & 0.1289 & 0.1124 & 1.7537 \\
AR(1) Coefficient of Investment & 0.7489 & 0.6191 & 2.8413 & 0.3628 & 0.3250 & 0.8649 \\
Mean of Net Equity Issuance & -0.0126 & -0.0134 & 0.0929 & -0.0263 & -0.0256 & -0.0808 \\
Std of Net Equity Issuance & 0.0132 & 0.0133 & -0.0069 & 0.0195 & 0.0206 & -0.0654 \\
Mean of Market-too-Book & 1.7516 & 2.1066 & -1.4280 & 4.1517 & 3.6097 & 2.4812 \\
Std of Market-to-Book & 1.4383 & 1.4680 & -0.1260 & 3.0941 & 2.6047 & 2.7475 \\
Mean of Dividend & 0.0168 & 0.0153 & 0.8191 & 0.0362 & 0.0336 & 1.7910 \\
Std of Dividend & 0.0108 & 0.0100 & 0.0467 & 0.0232 & 0.0220 & 0.0545 \\
SOA of Dividend & 0.2250 & 0.2387 & -0.2513 & 0.1788 & 0.1711 & 0.1472 \\
Mean Turnover & 0.0247 & 0.0229 & 0.6015 & 0.0271 & 0.0262 & 0.3314 \\
Corr btw Return and Turnover & -0.0444 & -0.0415 & -0.1424 & -0.0899 & -0.0851 & -0.1288 \\
------------ & -5 \\
Difference in SOA (negative indicator for smoothness), High Reputation-Low Reputation: & 0.0475 \\
Difference in Turnover-induced Dividend Smoothing, Low Reputation-High Reputation: & $15.65 \%$ \\
\hline \hline
\end{tabular}


Table 9: Subsample Estimation: Executive with High versus Low Stock Compensation

Table 9 presents the subsample estimation results obtained by splitting firms based on the executives' compensation structure. The sample consists of non-financial and non-utility firms in the 2013 Compustat and CRSP file over the period 1992-2011. The estimation is done with simulated method of moments (SMM), which chooses structural parameters by matching the moments from a simulated panel of firms to the corresponding moments from the actual data. The "High Stock/Cash Compensation" subsample consists of the one-third of firms where the top executives receive a higher ratio of stock-based compensation. The "Low Stock/Cash Compensation" subsample consists of the one-third of firms where the top executives receive a higher ratio of cash-based compensation.

\begin{tabular}{|c|c|c|c|c|c|c|}
\hline & \multicolumn{3}{|c|}{$\begin{array}{l}\text { High Stock/Cash } \\
\text { Compensation }\end{array}$} & \multicolumn{3}{|c|}{$\begin{array}{c}\text { Low Stock/Cash } \\
\text { Compensation }\end{array}$} \\
\hline & Actual & Simulated & $T$-stat & Actual & Simulated & $T$-stat \\
\hline Coefficient $\gamma_{y}$ in Equation (11) & 0.7190 & 0.6667 & 0.5542 & 0.6471 & 0.6581 & -0.1008 \\
\hline Coefficient $\gamma_{k}$ in Equation (11) & 0.4949 & 0.5297 & -0.5035 & 0.6972 & 0.7500 & -0.6258 \\
\hline Mean of Operating Income & 0.1679 & 0.1560 & 1.4647 & 0.1617 & 0.1489 & 1.5159 \\
\hline Std of Operating Income & 0.0650 & 0.0744 & -1.2319 & 0.0776 & 0.0719 & -0.7788 \\
\hline $\mathrm{AR}(1)$ Coefficient of Operating Income & 0.6716 & 0.6446 & 0.3551 & 0.7836 & 0.7452 & 0.4935 \\
\hline Mean of Investment & 0.0566 & 0.0491 & 1.0001 & 0.1353 & 0.1479 & -1.7421 \\
\hline Std of Investment & 0.0947 & 0.1180 & -2.9388 & 0.0573 & 0.0660 & -1.0574 \\
\hline AR(1) Coefficient of Investment & 0.9042 & 0.8320 & 1.6960 & 0.4402 & 0.4071 & 0.6169 \\
\hline Mean of Net Equity Issuance & -0.0122 & -0.0151 & 0.4503 & -0.0246 & -0.0179 & -1.1903 \\
\hline Std of Net Equity Issuance & 0.0145 & 0.0150 & -0.0635 & 0.0179 & 0.0189 & -0.1137 \\
\hline Mean of Market-too-Book & 1.8136 & 2.2193 & -1.7799 & 3.6328 & 3.0717 & 2.6967 \\
\hline Std of Market-to-Book & 1.4043 & 1.1815 & 1.2682 & 3.0132 & 2.7673 & 1.1143 \\
\hline Mean of Dividend & 0.0225 & 0.0226 & -0.0422 & 0.0269 & 0.0225 & 3.0164 \\
\hline Std of Dividend & 0.0174 & 0.0149 & 0.2014 & 0.0208 & 0.0245 & -0.3140 \\
\hline SOA of Dividend & 0.2181 & 0.2172 & 0.0155 & 0.1768 & 0.1687 & 0.1062 \\
\hline Mean Turnover & 0.0248 & 0.0236 & 0.5922 & 0.0276 & 0.0244 & 1.6230 \\
\hline Corr btw Return and Turnover & -0.0725 & -0.0672 & -0.2702 & -0.0652 & -0.0646 & -0.0236 \\
\hline
\end{tabular}

Difference in SOA (negative indicator for smoothness), High Stock/Cash-Low Stock/Cash: 0.0768

Difference in Turnover-induced Dividend Smoothing, Low Stock/Cash-High Stock/Cash: $15.81 \%$ 
Table 10: Subsample Estimation: Early versus Late Sample Period

Table 10 presents the estimation results obtained by splitting the sample based on time. The sample consists of non-financial and non-utility firms in the 2013 Compustat and CRSP file over the period 1992-2011. The "Early" subsample includes all firm-year observations in or before 2002; the "Late" subsample consists of all firm-year observations from 2003 and onwards. The estimation is done with simulated method of moments (SMM), which chooses structural parameters by matching the moments from a simulated panel of firms to the corresponding moments from the actual data.

\begin{tabular}{|c|c|c|c|c|c|c|}
\hline & \multicolumn{3}{|c|}{ Early } & \multicolumn{3}{|c|}{ Late } \\
\hline & Actual & Simulated & $T$-stat & Actual & Simulated & $T$-stat \\
\hline Coefficient $\gamma_{y}$ in Equation (11) & 0.6909 & 0.7056 & -0.1626 & 0.5531 & 0.5290 & 0.2624 \\
\hline Coefficient $\gamma_{k}$ in Equation (11) & 0.4027 & 0.5172 & -1.4174 & 0.5578 & 0.5300 & 0.3011 \\
\hline Mean of Operating Income & 0.1685 & 0.1412 & 3.3909 & 0.1445 & 0.1372 & 1.0000 \\
\hline Std of Operating Income & 0.0502 & 0.0616 & -1.5808 & 0.0815 & 0.0721 & 1.2420 \\
\hline AR(1) Coefficient of Operating Income & 0.7462 & 0.7141 & 0.4157 & 0.6940 & 0.6981 & -0.0574 \\
\hline Mean of Investment & 0.0869 & 0.0757 & 1.6020 & 0.1306 & 0.1087 & 2.5548 \\
\hline Std of Investment & 0.0591 & 0.0535 & 0.6124 & 0.0381 & 0.0428 & -0.6356 \\
\hline AR(1) Coefficient of Investment & 0.6524 & 0.5524 & 2.7532 & 0.4720 & 0.4814 & -0.2260 \\
\hline Mean of Net Equity Issuance & -0.0176 & -0.0172 & -0.0659 & -0.0212 & -0.0182 & -0.5411 \\
\hline Std of Net Equity Issuance & 0.0175 & 0.0167 & 0.0907 & 0.0153 & 0.0143 & 0.0718 \\
\hline Mean of Market-too-Book & 2.7641 & 2.4485 & 1.3059 & 2.7230 & 2.7651 & -0.1993 \\
\hline Std of Market-to-Book & 2.4931 & 2.4307 & 0.4019 & 2.2998 & 2.4494 & -0.8841 \\
\hline Mean of Dividend & 0.0241 & 0.0241 & -0.0216 & 0.0229 & 0.0236 & -0.4744 \\
\hline Std of Dividend & 0.0177 & 0.0165 & 0.0885 & 0.0184 & 0.0196 & -0.0726 \\
\hline SOA of Dividend & 0.2163 & 0.2336 & -0.2808 & 0.1664 & 0.1503 & 0.2233 \\
\hline Mean Turnover & 0.0237 & 0.0241 & -0.2517 & 0.0283 & 0.0288 & -0.2153 \\
\hline Corr btw Return and Turnover & -0.0869 & -0.0791 & -0.2991 & -0.0470 & -0.0463 & -0.0239 \\
\hline \multicolumn{6}{|c|}{ Difference in Speed Of Adjustment (negative indicator for smoothness), Early-Late: } & 0.0589 \\
\hline \multicolumn{6}{|c|}{ Difference in Turnover-induced Dividend Smoothing, Late-Early: } & $9.97 \%$ \\
\hline
\end{tabular}


Table 11: Robustness

Table 11 reports the parameter estimates and the magnitude of excess dividend smoothing under alternative model specifications. The clustered standard errors for the estimated coefficients are reported in parentheses. Excess dividend smoothing is calculated following the procedures described in Section 4.3. The first two robustness checks resolve the model, taking the parameter values in the baseline case and the estimates from other papers. $\alpha_{0}, \alpha_{1} \& \alpha_{2}$ in (1) represent the fixed and convex capital adjustment costs, and the asymmetry in buying and selling prices. $\rho_{\xi}$ and $\sigma_{\xi}$ in (2) measure the persistence and standard deviation of the stochastic equity issuance cost. $q$ in (3) is the cost for earnings management, and its value is calibrated to match the average firm-level unsigned abnormal accrual. The remaining five robustness checks re-estimate the model using simulated method of moments (SMM). $\eta_{z}$ in (6) captures the sensitivity of executive compensation to the perceived firm productivity, $\hat{z}_{t} . c_{p}$ in (7) stands for the board's personal turnover cost.

\begin{tabular}{|c|c|c|c|c|c|c|c|c|c|c|c|c|c|}
\hline \multicolumn{13}{|c|}{ 1. Lumpy investment } & Excess Div \\
\hline$\rho_{z}$ & $\sigma_{z}$ & $\sigma_{s}$ & $\theta$ & $\delta$ & $\nu$ & $f_{0}$ & $f_{1}$ & $f_{2}$ & $c$ & $\alpha_{0} \times 10^{2}$ & & & Smoothing \\
\hline 0.697 & 0.287 & 0.074 & 0.550 & 0.100 & 0.063 & 0.025 & 0.063 & 0.712 & 0.411 & 0.400 & 0.043 & 0.033 & $37.45 \%$ \\
\hline \multicolumn{13}{|c|}{ 2. Stochastic issuance cost } & Excess Div \\
\hline$\rho_{z}$ & $\sigma_{z}$ & $\sigma_{s}$ & $\theta$ & $\delta$ & $\nu$ & $f_{0}$ & $f_{1}$ & $f_{2}$ & $c$ & $\rho_{\xi} \times 10^{3}$ & $\sigma_{\xi}$ & & Smoothing \\
\hline 0.697 & 0.287 & 0.074 & 0.550 & 0.100 & 0.063 & 0.025 & 0.063 & 0.712 & 0.411 & 0.037 & 0.974 & & $44.08 \%$ \\
\hline \multicolumn{13}{|c|}{ 3. Earning management } & Excess Div \\
\hline$\rho_{z}$ & $\sigma_{z}$ & $\sigma_{s}$ & $\theta$ & $\delta$ & $\nu$ & $f_{0}$ & $f_{1}$ & $f_{2}$ & $c$ & $q$ & & & Smoothing \\
\hline 0.697 & 0.287 & 0.074 & 0.550 & 0.100 & 0.063 & 0.025 & 0.063 & 0.712 & 0.411 & 0.643 & & & $31.57 \%$ \\
\hline \multicolumn{13}{|c|}{ 4. Executives' outside opportunities } & Excess Div \\
\hline$\rho_{z}$ & $\sigma_{z}$ & $\sigma_{s}$ & $\theta$ & $\delta$ & $\nu$ & $f_{0}$ & $f_{1}$ & $f_{2}$ & $c$ & & & & Smoothing \\
\hline 0.647 & 0.216 & 0.049 & 0.558 & 0.106 & 0.072 & 0.024 & 0.077 & 0.749 & 0.480 & & & & $29.14 \%$ \\
\hline$(0.174)$ & $(0.005)$ & $(0.010)$ & $(0.187)$ & $(0.027)$ & $(0.001)$ & $(0.020)$ & $(0.011)$ & $(0.046)$ & $(0.002)$ & & & & \\
\hline
\end{tabular}


5. Executives' stock options

$\begin{array}{cccccccccc}\rho_{z} & \sigma_{z} & \sigma_{s} & \theta & \delta & \nu & f_{0} & f_{1} & f_{2} & c \\ 0.719 & 0.252 & 0.088 & 0.565 & 0.117 & 0.098 & 0.027 & 0.122 & 0.847 & 0.569 \\ (0.250) & (0.008) & (0.026) & (0.122) & (0.043) & (0.003) & (0.014) & (0.021) & (0.031) & (0.015)\end{array}$

Excess Div Smoothing $33.01 \%$

6. Executives' risk aversion

$\begin{array}{ccccccccccc}\rho_{z} & \sigma_{z} & \sigma_{s} & \theta & \delta & \nu & f_{0} & f_{1} & f_{2} & c & \eta_{z} \\ 0.601 & 0.275 & 0.051 & 0.618 & 0.125 & 0.055 & 0.027 & 0.098 & 0.465 & 0.232 & 0.061 \\ (0.052) & (0.064) & (0.0326) & (0.21) & (0.014) & (0.007) & (0.008) & (0.068) & (0.072) & (0.028) & (0.005)\end{array}$

Excess Div Smoothing $52.33 \%$

7. Board's entrenchment

$\begin{array}{ccccccccccc}\rho_{z} & \sigma_{z} & \sigma_{s} & \theta & \delta & \nu & f_{0} & f_{1} & f_{2} & c & c_{p} \\ 0.641 & 0.256 & 0.087 & 0.596 & 0.098 & 0.062 & 0.016 & 0.056 & 0.612 & 0.421 & 4.683 \\ (0.206) & (0.009) & (0.012) & (0.130) & (0.002) & (0.028) & (0.050) & (0.012) & (0.040) & (0.017) & (0.581)\end{array}$

Excess Div Smoothing $37.54 \%$

8. Asymmetric learning speed

\begin{tabular}{|c|c|c|c|c|c|c|c|c|c|c|}
\hline $\begin{array}{c}\rho_{z} \\
0.695 \\
(0.063)\end{array}$ & $\begin{array}{c}\sigma_{z} \\
0.300 \\
(0.014)\end{array}$ & $\begin{array}{c}\sigma_{s} \\
0.082 \\
(0.047)\end{array}$ & $\begin{array}{c}\theta \\
0.635 \\
(0.201)\end{array}$ & $\begin{array}{c}\delta \\
0.100 \\
(0.007)\end{array}$ & $\begin{array}{c}\nu \\
0.080 \\
(0.060)\end{array}$ & $\begin{array}{c}f_{0} \\
0.027 \\
(0.007)\end{array}$ & $\begin{array}{c}f_{1} \\
0.059 \\
(0.012)\end{array}$ & $\begin{array}{c}f_{2} \\
0.735 \\
(0.215)\end{array}$ & $\begin{array}{c}c \\
0.430 \\
(0.007)\end{array}$ & $\begin{array}{r}\text { Smoothing } \\
40.78 \%\end{array}$ \\
\hline
\end{tabular}

